\title{
Household bargaining over fertility: Theory and evidence from Malaysia ${ }^{\succsim}$
}

\author{
Imran Rasul * \\ Department of Economics, University College London, Drayton House, 30 Gordon Street, London WC1E 6BT, United Kingdom \\ CEPR, United Kingdom
}

Received 14 November 2005; received in revised form 24 April 2006; accepted 28 February 2007

\begin{abstract}
We develop and test a model of household bargaining over fertility when transfers between spouses are possible. The model makes precise how the fertility preferences of each spouse translate into fertility outcomes. We show this depends on whether or not spouses can commit to their future actions within marriage. If couples bargain with commitment, fertility outcomes take account of both spouses' fertility preferences and do not depend on the threat point in marital bargaining. If couples bargain without commitment, the influence of each spouse's fertility preference on fertility outcomes depends on the relevant threat point in marital bargaining, and the distribution of bargaining power. We test the models using household data from the Malaysia Family Life Survey. This data set contains information on each spouse's desired fertility level, as well as fertility outcomes. We exploit differences in threat points in marital bargaining across ethnic groups to help identify the underlying bargaining model. The evidence suggests couples bargain without commitment.
\end{abstract}

(C) 2007 Elsevier B.V. All rights reserved.

JEL classification: J12; J13; O12

Keywords: Commitment; Fertility; Household bargaining

\footnotetext{
Is I thank the editor, Mark Rosenzweig, and an anonymous referee for comments that have helped improve the paper. I have also benefited from discussions with Oriana Bandiera, Tim Besley, Richard Blundell, Robin Burgess, Anne Case, Andrew Chesher, Markus Goldstein, Valentino Larcinese, Alan Manning, Michele Piccione, Andrea Prat, Yoram Weiss and seminar participants at Bocconi, Bonn, Brown, Chicago GSB, Essex, IFS, IIES, LSE, Mannheim, Maryland, Michigan, Northwestern, Stanford GSB, Warwick, the World Bank, and Yale SOM. I thank Marcia Schafgans and Charles Hirschman for help with obtaining the data. All errors remain my own.

* Department of Economics, University College London, Drayton House, 30 Gordon Street, London WC1E 6BT, United Kingdom. Tel.: +44 207679 5853; fax: +44 2079162775 .

E-mail address: i.rasul@ucl.ac.uk.
}

\section{Introduction}

This paper develops and tests a model of household bargaining over fertility when transfers between spouses are possible. The aim of the analysis is to make precise how the fertility preferences of each spouse translate into fertility outcomes. This sheds light both on how conflicts between spouses over fertility are resolved, and the subsequent distribution of household resources. ${ }^{1}$

\footnotetext{
${ }^{1}$ It is well documented that there are significant differences in men and women's fertility preferences in many developing countries including Malaysia, which is our empirical setting (Leung, 1987; Mason and Taj, 1987).
} 
Key to the analysis is whether spouses can commit to their future actions in marriage once they have chosen a fertility level. Suppose first that spouses are able to commit to ex ante agreements on their behavior within marriage. The future actions of either spouse can then be agreed to at any time, including in a pre-marital contract. With commitment, this agreement is assumed enforceable at any stage of marriage. We show fertility outcomes are then efficient and take account of both spouse's desired fertility level.

Now suppose couples are unable to commit ex ante to their future actions within marriage. Such actions may for example include their investments into child quality. While such future actions can be discussed, they cannot be committed to ex ante. Non-commitment may stem from actions being non-observable or non-verifiable. It will not then be possible to write an agreement based on these actions because such contracts are not enforceable by third parties.

The key insight for household decision making when actions cannot be committed to is that marital bargains are subject to ex post renegotiation after fertility investments are sunk, and this alters spouses' ex ante investment incentives. This standard hold-up problem has consequences both for the efficiency of fertility outcomes, and the allocation of household resources.

With non-commitment, both spouses' preferences are weighted in determining the equilibrium number of children, although these weights are in general different, and may even be zero. In particular, the influence of each spouse's fertility preference on fertility outcomes depends on the relevant threat point in marital bargaining, and the distribution of bargaining power.

We take the models to the data using the Malaysia Family Life Survey (MFLS). This is two-wave household panel where both spouses are interviewed on each occasion. Importantly, the survey collects detailed information on each spouse's fertility preferences. We relate fertility outcomes at the end of women's fertility period in the second wave of data, to the fertility preferences of both spouses as expressed 12 years earlier, in the first wave of data. ${ }^{2}$

In line with the existing evidence (Leung, 1987; Mason and Taj, 1987), we find significant differences between spouses in their desired fertility. On average,

\footnotetext{
${ }^{2}$ In contrast, much of the existing literature has exploited data such as the World Fertility Survey, that only contains the wife's fertility preference. Furthermore, nearly all the previous literature has used data with a time span of between three and seven years from when preferences are expressed until fertility outcomes are observed (Freedman et al., 1980; Thomson et al., 1990).
}

husbands prefer significantly more children than their wives.

Malaysia is an ethnically diverse country and we exploit important differences in how marriage markets operate across ethnic groups, and hence the relevant threat point in marital bargaining, to help identify the underlying model of bargaining. As documented in more detail later, among Malays, divorce rates over the study period are among the highest in the world. For these couples, the relevant threat point in marital bargaining is divorce. In contrast, for the Chinese in Malaysia, divorce is rare and the relevant threat point relates more closely to some non-cooperative outcome within marriage (Lundberg and Pollak, 1993; Chen and Woolley, 2001). ${ }^{3}$

If couples bargain with commitment, theory predicts these different threat points in marital bargaining across ethnic groups, should have no effect on how fertility preferences translate into fertility outcomes. If couples bargain without commitment, then the outside option in marital bargaining shapes how the fertility preferences of each spouse translate into fertility outcomes.

The central empirical results are that in Malay households, both spouse's fertility preferences have an equal, positive, and significant effect on fertility outcomes. In contrast, in Chinese households, only the wife's preference determines fertility outcomes. The results are robust to controlling for other individual and household determinants of fertility, and to using an estimation technique that accounts for the discreteness of fertility outcomes. However, a number of econometric concerns remain.

First, there may be unobserved time invariant household determinants of fertility preferences and fertility outcomes. To address this concern we apply a transformation analogous to first-differencing fertility outcomes between the two waves of data. We then estimate how each spouse's desired number of additional children relates to the additional number of children born between the two waves of data.

Second, preferences may be endogenously determined by unobserved factors that also drive fertility outcomes. Alternatively, preferences may be measured with error. We address these concerns using an instrumental variables approach that exploits information on the characteristics of each spouse's own parent, to instrument for preferences.

These econometric concerns obviously apply equally to all couples. However due to limited sample sizes in

\footnotetext{
${ }^{3}$ Intermarriage across ethnic groups is almost non existent in the time period we study.
} 
the MFLS data, we are only able to address them for Malays. When doing so, we continue to find that among Malay couples, both spouse's fertility preferences have an equal, positive, and significant effect on fertility outcomes.

Mapping the results back to theory, behavior among Malay couples is consistent with them bargaining with or without commitment. In contrast, for Chinese couples, as only the wife's preference determines fertility outcomes, their behavior can only be reconciled with a model of bargaining without commitment.

This leads to one of two conclusions. First, it may be that Malay couples can bargain with commitment and Chinese couples cannot. This interpretation lacks intuitive appeal if we view the ability of couples to commit or not as a fundamental characteristic underlying household behavior, and not something some couples can do, and others cannot. A second interpretation is that all couples bargain without commitment. The variation in outcomes across couples is then explained by differences in threat points in marital bargaining across ethnic groups. To distinguish between these interpretations, we provide evidence that within each ethnic group, how each spouse's preference translates into outcomes depends on the distribution of household bargaining power. This is consistent with households bargaining without commitment.

The balance of evidence therefore suggests that all households bargain without commitment.

The paper makes three contributions to the literature. First, we develop and test a general model of household decision making over fertility. The model makes precise how spousal conflicts over desired fertility are resolved, and the role of commitment in marital bargaining. Noncommitment leads to marital bargains being subject to ex post renegotiation which has both efficiency and distributional consequences.

A second contribution is the explicit inclusion of preferences in a model of decision making over fertility. While many papers in the demographic literature have shown a correlation between reported fertility preferences and subsequent fertility outcomes, the interpretation of those correlations has hitherto been far from obvious. Moreover, by exploiting a data set containing information on each spouse's desired fertility we are able to perform direct tests of household bargaining models, rather than having to follow an inferential approach that has been previously used in the literature (Thomas, 1990).

Finally, we contribute to the literature on household decision making. The benchmark model of household behavior has been the unitary model (Becker, 1981). While this generates a rich set of predictions for price and income effects on fertility, it remains silent on how conflicts between spouses over fertility are resolved. Modelling fertility as the outcome of a bargaining process provides a natural way in which to introduce conflicts. However, in contrast to existing household bargaining models (Manser and Brown, 1980; McElroy and Horney, 1981; Chiappori, 1988), we move away from the implicit assumption that households bargain with commitment, and do not therefore assume households necessarily make efficient fertility decisions.

The paper is organized into five sections. Section 2 develops the model of bargaining over fertility. Section 3 documents differences in marriage markets across ethnic groups in Malaysia, and describes the MFLS data. Section 4 presents the main results, additional evidence exploring further implications of theory, and addresses econometric concerns. Section 5 concludes.

\section{A model of bargaining over fertility}

We present a model of bargaining in marriage over fertility. This makes precise that the ability of spouses to commit to ex ante agreements on fertility, affects how the fertility preferences of each spouse translate into actual fertility outcomes. The main intuitions can be grasped in the general framework presented in Section 2.1. To then bring the theory to the data, we move to specific functional forms in Section 2.2.

\subsection{General payoffs}

The household comprises a married husband $(h)$ and wife $(w)$. Spouse $i$ 's payoff in marriage, $U^{i}$, depends on the following factors. First, there are some private gains from marriage, $v_{i}$. Second, there are other benefits from marriage that depend both on the number of children, $q$, and the desired number of children, $\pi_{i}^{*}, V^{i}\left(q, \pi_{i}^{*}\right)$. Both spouses are therefore assumed to care about fertility, and in line with earlier literature, children are assumed to be a public good within marriage (Weiss and Willis, 1985). Both spouses fertility preferences and private gains from marriage are assumed to be common knowledge. The private gain is assumed transferable across spouses. As a result, all divisions of the marital surplus are feasible.

We make a simplifying assumption that only the wife makes a sunk investment, $q$, to produce children. 
This leads to exactly $q$ children being born ex post. Wives bear the cost of investing, $c(q)$, where $c(q)$ is non-negative and convex. These costs include those arising from the biology of child rearing, such as the time devoted to pregnancy, childbirth, and lactation over the fertility period. Husband and wife's payoffs in marriage are then given by;

$$
\begin{aligned}
& U^{h}={ }_{h}+V^{h}\left(q, \pi_{h}^{*}\right) \\
& U^{w}={ }_{w}+V^{w}\left(q, \pi_{w}^{*}\right)-c(q) .
\end{aligned}
$$

If the marriage breaks up, the partners no longer obtain any private benefits from marriage. We also assume there is no childbearing outside of marriage so that women no longer incur the costs of producing children. ${ }^{4}$ Hence spouse $i$ 's payoff in singlehood is;

$\bar{U}^{i}=\bar{V}^{i}\left(q, \pi_{i}^{*}\right)$,

where $q$ is the number of children, if any, produced during marriage. There is assumed to be some gain to being married over being single, so there is a positive surplus to be bargained over. ${ }^{5}$

Although this framework generates a rich set of predictions on behavior, this comes at the cost of some considerable simplifications on real world aspects of the fertility process. It is important to be clear from the outset on the robustness of the results to these simplifying assumptions.

First and foremost, husbands surely also make investments into producing children. The aim of the analysis is to understand how spouses' fertility preferences relate to fertility outcomes, and how the role of preferences changes depending on the ability of spouses to commit to their actions within marriage. As detailed throughout, the qualitative nature of these key results is largely unchanged if both spouses can invest. Moreover, as we assume all divisions of the marital surplus are feasible, the results are also robust to allowing spouses to share the costs of investing into fertility. Indeed, with commitment in marriage, we show that the wife is fully compensated for

\footnotetext{
${ }^{4}$ Births out-of-wedlock are almost non-existent in Malaysia over the period of study.

${ }^{5}$ By revealed preference, these gains from marriage must exist. They may arise from specialization in home and market production, economies of scale, the provision of insurance, and risk sharing, among others.
}

her investment costs through transfers from her husband. ${ }^{6}$

Second, deciding the number of children to have is an inherently dynamic decision making process. We capture such dynamics by considering two periods in marriage - one at the start of marriage when fertility investments are chosen, and one after these investments are sunk, and bargaining takes place. The payoffs in marriage, $U^{i}$, should therefore be thought of as the present value of benefits from marriage, and the payoffs in singlehood, $\bar{U}^{i}$, should be thought of as the present value of returning to the pool of singles and potentially remarrying.

While this allows a direct mapping between the two periods in the theoretical analysis to the two periods available in the data, this simplification raises other issues such as the potential endogeneity of fertility preferences. This arises if for example parents update their fertility preferences as they learn the true costs and benefits of children during marriage. We address concerns on the endogenous formation of preferences in the empirical analysis.

Third, inevitably some aspects of household decision making - such as the trade-off between child quantity and quality - are ignored altogether, both to make tractable the theoretical analysis, and because of data limitations. Such extensions remain open for future research.

With these caveats and concerns in mind, we now turn to the analysis. We focus on highlighting the key aspect of marital bargaining the model brings to the fore. Namely, the ability of spouses to commit to ex ante agreements on behavior within marriage affects how each spouse's fertility preference translates into fertility outcomes.

\subsubsection{Marriage with commitment}

Suppose spouses are able to commit ex ante on their behavior within marriage. Any future actions within marriage of either spouse can then be specified at any time, including in a pre-marital contract. This implicit

\footnotetext{
${ }^{6}$ Allowing husbands to also invest into producing children would also force us to make additional assumptions on the production function for children. This raises further complications without providing additional insights on the nature of marital bargaining. In the model of marriage developed here, it is as if the wife always retains access to some hidden action, such as contraceptive use, that allows her to uniquely control her fertility level. The husband can then only provide incentives to his wife to change her fertility level through the use of transfers in marital bargaining, not physical coercion. This justification also fits the relevant empirical facts - contraceptives have been available in Malaysia since the 1960s, and a quarter of women in our sample report having used them.
} 
contract specifies investments into fertility, and transfers across spouses in marriage once fertility investments are sunk. In a world of commitment, this agreement is assumed enforceable at any stage of marriage.

The relevant outside option for couples at the time of agreeing on such a marital contract, is to separate before investments into fertility are undertaken and children are born. The payoff to spouse $i$ in the case of a breakdown in marital bargaining is then $\bar{V}^{i}\left(0, \pi_{i}^{*}\right)$. This outside option may depend on opportunities for remarriage, but is independent of the number of children in the current marriage as these investments have not yet been undertaken.

We can now determine the equilibrium fertility and transfers. To first pin down the transfers across partners, we assume spouses Nash bargain over the division of the marital surplus. We denote the bargaining power of husbands as $\theta$ and the transfer as $t$. The transfer is defined to be positive if it is from husband to wife. The equilibrium Nash bargained transfer, when ex ante agreements can be committed to, $t^{\mathrm{C}}$, is therefore given by;

$$
\begin{aligned}
t^{\mathrm{C}}= & (1-\theta)\left[v_{h}+V^{h}\left(q, \pi_{h}^{*}\right)-\bar{V}^{h}\left(0, \pi_{h}^{*}\right)\right] \\
& -\theta\left[v_{w}+V^{w}\left(q, \pi_{w}^{*}\right)-\bar{V}^{w}\left(0, \pi_{w}^{*}\right)-c(q)\right] .
\end{aligned}
$$

The transfer a spouse receives increases in their own bargaining power. If one spouse retains all the bargaining power, they appropriate the entire marital surplus and their partner remains indifferent between having $q$ children in marriage and remaining single with no children. Note that the transfer fully compensates the wife for her costs of investing. ${ }^{7}$

The spouse that, for a given fertility preference, gains more from having children in marriage relative to remaining single without children, transfers more to their partner, other things equal. Hence the pre-marital contract accounts for differences in fertility preferences across spouses.

The wife chooses her investment to maximize her ex ante payoff, taking account of the transfers she receives;

$\max _{q} v_{w}+V^{w}\left(q, \pi_{w}^{*}\right)+t^{\mathrm{C}}-c(q)$.

\footnotetext{
${ }^{7}$ A woman's bargaining power will depend on her attractiveness in the marriage market. This in turn depends partly on her future fecundity and quality as a mother. As transfers to the wife increase in her bargaining power, this captures the intuition that with commitment, women that are more attractive in the marriage market are able to negotiate pre-marital contracts that are more attractive to them.
}

Husbands' fertility preferences therefore influence fertility outcomes through their effect on transfers within marriage. Substituting in for $t^{\mathrm{C}}$, it is straightforward to show the equilibrium number of children when ex ante agreements can be committed to, $q^{\mathrm{C}}$, satisfies the standard Lindahl-Samuelson condition for public goods; ${ }^{8}$

$V_{q}^{h}\left(q^{\mathrm{C}}, \pi_{h}^{*}\right)+V_{q}^{w}\left(q^{\mathrm{C}}, \pi_{w}^{*}\right)=c^{\prime}\left(q^{\mathrm{C}}\right)$

This result that marital bargaining leads to an efficient outcome is a straightforward application of the Coase theorem. To summarize;

Result 1. With commitment in marriage, investments into fertility are efficient. Both spouses' preferences are weighted in determining the equilibrium number of children.

Spousal preferences determine the fertility outcomes through their effect on the payoff within marriage, $V^{i}($.). The relationship between preferences and payoffs in the case of a breakdown in marital bargaining, $\bar{V}^{i}($.$) , is irrelevant in determining the$ equilibrium fertility level when ex ante agreements can be committed to. Note finally that the equilibrium fertility level is independent of the distribution of bargaining shares across spouses. All of these features of the model will be exploited later in the empirical analysis. ${ }^{9}$

\subsubsection{Marriage without commitment}

We now consider a world in which ex ante agreements on behavior in marriage cannot be committed to. Such future actions may relate to investments into child quality for example. While these future actions can certainly be discussed, they cannot be committed to ex ante. Non-commitment may stem from actions being neither observable nor verifiable. It will not then be possible to write an agreement based on them because such contracts are not enforceable by third parties outside the household. Alternatively, some

\footnotetext{
${ }^{8}$ Hence when there is commitment in marriage, it is as if the wife chooses her investment to maximize the total marital surplus, $U^{h}+U^{w}-\bar{U}^{h}-\bar{U}^{w}$. This is in line with a unitary model of household decision making.

${ }^{9}$ This is an application of the results in Bergstrom and Cornes (1983). They show the Pareto optimal level of public goods provision is independent of the distribution of resources for the class of utility functions $U^{i}($.) considered here.
} 
actions may be time inconsistent, or not credible in light of unanticipated shocks. ${ }^{10}$

The main insight for household decision making over fertility when actions cannot be committed to, is that marital bargains are then subject to ex post renegotiation after fertility investments are sunk. Spouses cannot credibly commit not to renegotiate. Ex post renegotiation over the marital surplus prevents the wife from appropriating the full marginal benefit of her ex ante fertility investment. This alters the wife's investment incentives. This has consequences both for the efficiency of household decisions, as well as the distribution of resources across spouses.

The household therefore faces a standard hold-up problem (Grossman and Hart, 1986; Hart and Moore, 1990). As is well recognized, these general implications of non-commitment would remain if we modelled both spouses as making fertility investments. ${ }^{11}$

To see the implications for household outcomes when couples bargain without commitment, we need to specify spousal payoffs if bargaining breaks down. Given that bargaining takes place after investments are made, spouse $i$ 's payoff in this case is $\bar{V}^{i}\left(q, \pi_{i}^{*}\right)$. The interpretation of this payoff depends on the relevant threat point in marriage.

It is standard in the literature on household bargaining to assume the threat point in marriage is divorce. If so, $V^{i}\left(q, \pi_{i}^{*}\right)$ captures the present value of returning to the pool of singles and potentially remarrying. This value depends on both the number of children from the current marriage and fertility preferences. If divorce is not a credible threat, an alternative interpretation is that $V^{i}\left(q, \pi_{i}^{*}\right)$ captures the value of some non-cooperative outcome within marriage. Again this will in general depend on the number of children from the current marriage and fertility preferences. As discussed in more detail later, both cases will be relevant in the Malaysian context. $^{12}$

\footnotetext{
${ }^{10}$ Unanticipated shocks to bargaining power may be relevant for Malaysia during the period of study, when the economy experienced rapid economic growth that led to rising female wages relative to male wages for example.

${ }^{11}$ A case in which renegotiation would have no affect on ex ante investments would be if one partner could make take-it-or-leave-it offers during the renegotiation period. This is unlikely to be the case in marital bargaining where both spouses retain some bargaining power in marriage.

${ }^{12}$ In either case the properties of $V^{i}\left(q, \pi_{i} *\right)$ may depend on whether the number of children $q$ is greater than or less than the spouse's desired fertility, $\pi_{i} *$.
}

We are now able to solve for the equilibrium transfers and fertility level. We solve the model backwards, considering first transfers in marriage. These are determined in a similar fashion as in the model of marriage with commitment. The key difference with noncommitment is that the relevant threat point in bargaining is $V^{i}\left(q, \pi_{i}^{*}\right)$, and the wife no longer recovers her sunk costs of investment. The equilibrium Nash bargained transfer with non-commitment, $t^{\mathrm{NC}}$, then is;

$$
\begin{aligned}
t^{\mathrm{NC}}= & (1-\theta)\left[v_{h}+V^{h}\left(q, \pi_{h}^{*}\right)-\bar{V}^{h}\left(q, \pi_{h}^{*}\right)\right] \\
& -\theta\left[v_{w}+V^{w}\left(q, \pi_{w}^{*}\right)-\bar{V}^{w}\left(q, \pi_{w}^{*}\right)\right] .
\end{aligned}
$$

As in a world of commitment, the division of the marital surplus depends both on the distribution of bargaining power across spouses, and on how fertility preferences determine each spouse's gains from marriage. We now solve for the equilibrium fertility outcome.

With non-commitment, the wife anticipates renegotiation later in marriage. She therefore chooses her investment to maximize her ex ante payoff;

$\max _{q} v_{w}+V^{w}\left(q, \pi_{w}^{*}\right)+t^{\mathrm{NC}}-c(q)$.

Substituting Eq. (6) into Eq. (7) and maximizing with respect to $\mathrm{q}$, the equilibrium fertility level with noncommitment, $q^{\mathrm{NC}}$, then satisfies the following first order condition; ${ }^{13}$

$$
\begin{aligned}
& (1-\theta)\left[V_{q}^{h}\left(q^{\mathrm{NC}}, \pi_{h}^{*}\right)+V_{q}^{w}\left(q^{\mathrm{NC}}, \pi_{w}^{*}\right)\right]+\left[\theta \bar{V}_{q}^{w}\left(q^{\mathrm{NC}}, \pi_{w}^{*}\right)\right. \\
& \left.-(1-\theta) \bar{V}_{q}^{h}\left(q^{\mathrm{NC}}, \pi_{h}^{*}\right)\right]=c^{\prime}\left(q^{\mathrm{NC}}\right) .
\end{aligned}
$$

This highlights two incentives the wife has to invest into fertility. First, she seeks to maximize the total payoff in marriage as in the case of commitment in marriage. This is captured in the first term on the LHS. Second, if on the margin, the wife's payoff when bargaining breaks down, is increasing relative to her husbands, so that $\bar{V}_{q}^{w}()>.\bar{V}_{q}^{h}($.$) , this increases the$ share of the marital surplus the wife appropriates in renegotiation. This increases her incentives to invest,

\footnotetext{
${ }^{13}$ If the wife were able to recover some fraction $\tau$ of her investment costs, this would add a $-\tau \theta c^{\prime}(q)$ term to the RHS of Eq. (8). This would not alter the main insights of the model.
} 
other things equal. This is captured in the second term on the LHS.

As in the case where spouses can commit to ex ante agreements, both spouses' fertility preferences determine the equilibrium number of children with non-commitment. However, in contrast to the case of commitment, the weight placed on each spouses preferences depends on their payoff if bargaining breaks down, and on their bargaining power. Hence even if spouses have identical preferences, and derive the same benefits from children in marriage and when bargaining breaks down, the effect each spouse's preference has on the fertility outcome still need not be the same. This result occurs despite the fact that only the wife is modelled to make fertility investments. The result stems from non-commitment in marriage, and this insight would be retained even if both partners are allowed to invest.

Comparison of the first order conditions (5) and (8) further reveals that fertility levels with non-commitment generally diverge from the efficient levels achieved with commitment.

Result 2. With non-commitment in marriage, investments into fertility are inefficient. Both spouses' preferences are weighted in determining the equilibrium number of children. The weight placed on each spouse's preference is partly determined by their payoff if bargaining breaks down and their bargaining power.

Results 1 and 2 highlight the different determinants of fertility outcomes depending on whether households can or cannot bargain with commitment. In addition, a comparison of the maximization problems (4) and (7) also reveals when non-commitment leads to overinvestment in fertility. This is so if the transfer to the wife increases more quickly as she invests, than does the husband's benefits from children in marriage, so that $\frac{\partial t^{\mathrm{NC}}}{\partial q}>V_{q}^{h}($.$) . In other words;$

Result 3. With non-commitment, overinvestment into fertility occurs if;

$$
\begin{aligned}
& {\left[\theta \bar{V}_{q}^{w}\left(q, \pi_{w}^{*}\right)-(1-\theta) \bar{V}_{q}^{h}\left(q, \pi_{h}^{*}\right)\right]>\theta\left[V_{q}^{h}\left(q, \pi_{h}^{*}\right)\right.} \\
& \left.\quad+V_{q}^{w}\left(q, \pi_{w}^{*}\right)\right] .
\end{aligned}
$$

The LHS of Eq. (9) captures the investment incentives of the wife arising from her capturing a greater share of the marital surplus during renegotiation. The RHS captures the marginal change in total gains from children in marriage. Hence overinvestment occurs if the investing partner appropriates a sufficiently greater share of the marital surplus as a result. Allowing spouses to share investment costs would not reverse the result, and may make overinvestment more likely. ${ }^{14}$

\subsection{Specific payoffs}

We now specify function forms for payoffs in marriage and if marital bargaining breaks down. This allows us to move towards an empirical specification that nests within it, both models of marital bargaining, and to tailor the model to capture some important features across ethnic groups in Malaysia that we exploit empirically.

Assumption 1. The payoff to spouses in marriage are;

$$
\begin{aligned}
& U^{h}={ }_{h}+\phi(q)-\frac{1}{2}\left(q-\pi_{h}^{*}\right)^{2} \\
& U^{w}={ }_{w}+\phi(q)-\frac{1}{2}\left(1-\pi_{w}^{*}\right)^{2}-c(q)
\end{aligned}
$$

The first term $v_{i}$, denotes the private benefit to i from marriage. The second term $\phi(q)$, captures in reduced form, the present value of the benefits from children, with $\phi(q)$ assumed concave. The third term captures how fertility preferences enter spousal payoffs in marriage. We consider an intuitive case in which spouses suffer a loss in utility if they do not achieve their preferred fertility level, all else equal. The utility loss increases in the divergence between fertility outcomes and preferences. The final term for the wife $c(q)$, captures the costs she incurs of having children.

Assumption 2. The payoff to spouse i if marital bargaining breaks down is;

$\bar{U}^{i}=\delta_{i} \phi(q)-\frac{\eta_{i}}{2}\left(q-\pi_{h}^{*}\right)^{2}$

If bargaining breaks down, spouses lose the private benefits of marriage. The benefits from children are assumed (weakly) lower if marital bargaining breaks down. The precise interpretation of the $\left(\delta_{i}, \eta_{i}\right)$ parameters depends on what the relevant threat point in marital bargaining is.

\footnotetext{
${ }^{14}$ If both partners can invest, then it can either be the case that $\theta \bar{V}_{q}^{w}\left(q, \pi_{w}^{*}\right) \geq(1-\theta) \bar{V}_{q}^{h}\left(q, \pi_{h}^{*}\right)$, or, $\theta \bar{V}_{q}^{w}\left(q, \pi_{w}^{*}\right) \leq(1-\theta) \bar{V}_{q}^{h}\left(q, \pi_{h}^{*}\right)$. Hence it remains possible that one spouse invests more than in a world with commitment, and the other invests less. Whether this leads to overinvestment depends on the assumptions made on the technology with which children are produced. By focusing on the case with one investor we avoid such complications without losing the fundamental insight of the bargaining model. Namely that with noncommitment, fertility levels can be inefficiently high if by having more children, one spouse is able to obtain a sufficiently greater share of the marital surplus in renegotiation, other things equal.
} 
Suppose couples divorce if marital bargaining breaks down. The $\delta_{i}$ parameters can then be interpreted as relating to the share of child custody enjoyed by spouse $i$, so that $\delta_{i} \leq 1 .{ }^{15}$ Having divorced, partners are free to remarry. Partners no longer suffer disutility from any divergence between their fertility preference and the number of children in the previous marriage, as they are free to pursue their fertility goals with future marriage partners. Hence with divorce as the relevant threat point to marital bargaining, $\eta_{i}=0$.

Suppose divorce is not a credible threat, so the relevant threat point in marital bargaining is for couples to reach some non-cooperative outcome within marriage. The $\delta_{i}$ parameters then capture the fact that the value of benefits from children may be lower if they are brought up in a household where parents conflict but do not divorce, so that $\delta_{i} \leq 1$. Moreover, as partners are unable to pursue their fertility goals with other marriage partners, they continue to suffer a loss from not having achieved their desired fertility level in the current marriage, so that $\eta_{i}=1$. $^{16}$

We now use these specific payoffs to make precise how the ability of spouses to commit to ex ante agreements on fertility, affects how each spouse's fertility preference translates both into fertility outcomes, and transfers across spouses in marriage.

\subsubsection{Marriage with commitment}

Suppose spouses bargain with commitment. Substituting the specific payoffs into Eq. (5), the equilibrium fertility level with commitment, $q^{\mathrm{C}}$, then satisfies the following first order condition;

$q^{\mathrm{C}}=\frac{1}{2}\left(\pi_{h}^{*}+\pi_{w}^{*}\right)+\phi^{\prime}\left(q^{\mathrm{C}}\right)-\frac{1}{2} c^{\prime}\left(q^{\mathrm{C}}\right)$

A number of implications follow. First, spousal preferences have equal weight in determining fertility outcomes. The divergence in preferences plays no role in determining the fertility outcome. Even if spouses conflict over desired fertility levels, it is the average of

\footnotetext{
15 This functional form captures a number of different ways to view the benefits from children in divorce. First, if children are a pure private good in divorce, $\delta_{i}$ relates to the fraction of the children's time endowment that is spent with spouse $i$, so that $\delta_{h}+\delta_{w}=1$. Second, if children are an impure public good in divorce, then $\delta_{i}$ captures both the time spent with spouse $i$ as well as the benefits obtained from children per se, so that $\delta_{i} \leq 1$. Third, if children are a pure public good in marriage and divorce, then $\delta_{h}=\delta_{w}=1$.

${ }^{16}$ In general, there is no reason to suppose these are the only threat points or interpretations that can be given. However, these two scenarios are found to be empirically relevant, and so we focus on them primarily to keep clear the exposition. In general, the $\eta^{i}$ parameters merely capture the extent to which preferences over the desired number of children still matter ex post.
}

these preferences that will, in part, determine the fertility outcome. Hence in line with a unitary model of the household, it is as if the household has a unique fertility preference given by the average of spouse's preferences. However, whether the equilibrium number of children actually lies above or below the average of spousal preferences, is ambiguous and depends on the sign of $\phi^{\prime}()-.\frac{1}{2} c^{\prime}(.){ }^{17}$

Second, spouses' payoffs if bargaining breaks down do not affect how each spouse's preference translates into fertility outcomes, so $q^{\mathrm{C}}$ is independent of the $\left(\delta_{i}, \eta_{i}\right)$ parameters. The fertility outcome is also independent of the distribution of bargaining power. The Nash bargained transfer across spouses is derived by substituting the specific payoffs into Eq. (3);

$$
\begin{aligned}
t^{\mathrm{C}}= & (1-\theta) v_{h}-\theta v_{w}+\frac{1}{2} \theta\left(q^{\mathrm{C}}-\pi_{w}^{*}\right)^{2} \\
& -\frac{1}{2}(1-\theta)\left(q^{\mathrm{C}}-\pi_{h}^{*}\right)^{2}+\frac{\eta_{h}}{2}(1-\theta) \pi_{h}^{* 2} \\
& -\frac{\eta_{w}}{2} \theta \pi_{w}^{* 2}+\left(\theta \delta_{w}-(1-\theta) \delta_{h}\right) \phi(0) \\
& +(1-2 \theta) \phi\left(q^{\mathrm{C}}\right)+\theta c\left(q^{\mathrm{C}}\right)
\end{aligned}
$$

The transfer depends on the private gains in marriage, the divergences between fertility outcomes and preferences, preferences themselves, and the cost and benefits of children in marriage. ${ }^{18}$

\subsubsection{Marriage without commitment}

Suppose spouses bargain without commitment.The equilibrium fertility level without commitment, $q^{\mathrm{NC}}$, then satisfies the following first order condition;

$$
\begin{aligned}
c^{\prime}\left(q^{\mathrm{NC}}\right)= & {\left[1-\theta\left(1-\eta_{w}\right)\right] \pi_{w}^{*}+\left[(1-\theta)\left(1-\eta_{h}\right)\right] \pi_{h}^{*} } \\
& +\left[(1-\theta) \eta_{h}-\theta \eta_{w}-2(1-\theta)\right] q^{\mathrm{NC}} \\
& +\left[2(1-\theta)+\theta \delta_{w}-(1-\theta) \delta_{h}\right] \phi^{\prime}\left(q^{\mathrm{NC}}\right)
\end{aligned}
$$

The equilibrium fertility level depends on both spouses' preferences, although not necessarily with the

\footnotetext{
${ }^{17}$ The bargaining framework therefore implies deviations between fertility outcomes and the average of spousal preferences need not arise because of mistakes, or unmet demand for contraception. The fact that fertility outcomes diverge from average spousal desires is an empirical regularity that holds in both developed and developing countries (Bongaarts, 2001).

${ }^{18}$ The reason why fertility preferences matter directly is because with commitment, the relevant outside option that couples face at the time of agreeing on the marital contract, is to separate before investments into fertility are undertaken and children are born. Hence $\bar{U}^{i}=\delta_{i} \phi(0)-\frac{\eta_{i}}{2}\left(0-\pi_{i}^{*}\right)^{2}$.
} 
same weight. In particular, spouses' payoffs if bargaining breaks down affect how each spouse's preference translates into fertility outcomes, so $q^{\mathrm{NC}}$ depends on the $\left(\delta_{i}, \eta_{i}\right)$ parameters, as well as on the distribution of bargaining power.

Suppose first the relevant threat point in marital bargaining is to divorce so that $\eta_{h}=\eta_{w}=0$. In this case, and only in this case, both spouse's preferences have equal weight in determining fertility outcomes. The actual weight attached to each spouse's preference is determined by the distribution of bargaining power in marriage.

Now suppose the relevant threat point in marital bargaining is some non-cooperative outcome within marriage so that $\eta_{h}=\eta_{w}=1$. In this case, and only in this case, the wife's preference alone has some positive weight attached to it in determining the fertility outcome. The husband's preference does not determine the fertility outcome. Moreover, the effect of the wife's fertility preference is independent of her bargaining power. In a more general setting when both spouses invest, as long as the wife's investment into fertility is relatively more important than her husbands, her preference will always matter more than her husband's for fertility outcomes.

Finally, the Nash bargained transfers are;

$$
\begin{aligned}
t^{\mathrm{NC}}= & (1-\theta) v_{h}-\theta v_{w}+\left((1-\theta)\left(1-\delta_{h}\right)\right. \\
& \left.-\theta\left(1-\delta_{w}\right)\right) \phi\left(q^{\mathrm{NC}}\right) \\
& -\frac{1}{2}(1-\theta)\left(1-\eta_{h}\right)\left(q^{N C}-\pi_{h}^{*}\right)^{2} \\
& +\frac{1}{2} \theta\left(1-\eta_{w}\right)\left(q^{N C}-\pi_{w}^{*}\right)^{2}
\end{aligned}
$$

These transfers depend on the private gains in marriage, the benefits from children in marriage, and the divergence between fertility outcomes and preferences. If the relevant threat point in marital bargaining is to divorce so $\eta_{h}=\eta_{w}=0$, the transfer from husband to wife decreases as the divergence between fertility outcomes and his preference increases. Similarly, the transfer increases as the divergence between fertility outcomes and his wife's preference increases.

Intuitively, when divorce is the relevant threat point, the surplus to be bargained over itself depends on the divergence between fertility outcomes and both spouses' preferences. Hence the transfer across spouses takes account of these divergences, and this in turn ensures both spousal preferences influence fertility outcomes.

If the relevant threat point is some non-cooperative outcome, the surplus to be bargained over is not determined by the divergence in fertility outcomes and preferences. These divergences do not then influence ex post transfers, and only the wife's preference drives fertility outcomes.
Note finally that by substituting the specific payoffs into the condition for overinvestment, Eq. (9), we cannot rule out that with non-commitment, there is overinvestment into fertility relative to the benchmark case of commitment in marriage.

\subsection{Summary}

Table 1 summarizes the predictions from theory. We do this both for the case when spouses can commit to ex ante agreements on fertility, and when they cannot, and how each of these change depending on the threat point in marital bargaining. In each case we highlight how (i) fertility outcomes relate to the fertility preferences of each spouse, and if this depends on the distribution of bargaining power; (ii) transfers from husband to wife depend on the divergence between fertility outcomes and the preferences of each spouse, and again if this depends on the distribution of bargaining power; (iii) transfers depend directly on fertility preferences.

The model provides a rich set of testable predictions to take to data. In the remainder of the paper, we focus on the empirical relation between fertility preferences and fertility outcomes, using the set of predictions summarized in the top half of Table 1 to shed light on the underlying nature of household bargaining. Reliable data on transfers between spouses however remains relatively scarce in nearly all household surveys. Hence we do not take this aspect of the theory to the data, and as such, this awaits future research.

\section{Empirical analysis}

\subsection{Background and data}

Malaysia is an ethnically diverse society - Malays account for $58 \%$ of the population, Chinese $26 \%$, Indians $7 \%$, and others $9 \%$. We exploit differences between the marriage markets of the Malay and Chinese ethnic groups to help identify the underlying model of marital bargaining. ${ }^{19}$

We first present evidence on two aggregate demographic trends. Fig. 1 shows for Malaysia, the time series for the fertility rate, defined as the number of live births per female, and the infant mortality rate, defined as the number of infant deaths per 1000 births. To provide some context for these figures, we also show the same series for Indonesia and the US.

\footnotetext{
19 There are an insufficient number of Indian households in the MFLS data to use them for the analysis.
} 
Table 1

Predictions of the Bargaining Model on Fertility Outcomes and Transfers Across Spouses

\begin{tabular}{|c|c|c|c|c|c|}
\hline \multirow[b]{4}{*}{ Fertility outcomes } & \multirow[t]{4}{*}{ Variable } & \multirow{2}{*}{\multicolumn{2}{|c|}{$\frac{\text { Marriage with commitment }}{\text { Threat point in marital bargaining: } \bar{V}^{i}\left(0, \pi_{i}^{*}\right)}$}} & \multirow{2}{*}{\multicolumn{2}{|c|}{$\begin{array}{l}\text { Marriage without commitment } \\
\text { Threat point in marital bargaining: } \bar{V}^{i}\left(q, \pi_{i}^{*}\right)\end{array}$}} \\
\hline & & & & & \\
\hline & & \multirow{2}{*}{$\begin{array}{l}\begin{array}{l}\text { Divorce } \\
\text { (Malays) }\end{array} \\
\eta_{i}=0\end{array}$} & \multirow{2}{*}{$\begin{array}{l}\text { Non-cooperation within marriage } \\
\text { (Chinese) } \\
\eta_{i}=1\end{array}$} & \multirow{2}{*}{$\begin{array}{l}\text { Divorce } \\
\text { (Malays) } \\
\eta_{i}=0\end{array}$} & \multirow{2}{*}{$\begin{array}{l}\text { Non-cooperation within marriage } \\
\text { (Chinese) } \\
\eta_{i}=1\end{array}$} \\
\hline & & & & & \\
\hline Wife's fertility preference & $\pi_{w}^{*}$ & $1 / 2$ & $1 / 2$ & $1-\theta$ & 1 \\
\hline Husband's fertility preference & $\pi_{h}^{*}$ & $1 / 2$ & $1 / 2$ & $1-\theta$ & 0 \\
\hline \multicolumn{6}{|l|}{ Transfers across spouses } \\
\hline Divergence between fertility outcome and wife's fertility preference & $\left(q-\pi_{w}^{*}\right) 2$ & $1 / 2 \theta$ & $1 / 2 \theta$ & $1 / 2 \theta$ & 0 \\
\hline Divergence between fertility outcome and husband's fertility preference & $\left(q-\pi_{h}^{*}\right)_{2}$ & $-1 / 2(1-\theta)$ & $-1 / 2(1-\theta)$ & $-1 / 2(1-\theta)$ & 0 \\
\hline Wife's fertility preference squared & $\pi_{h}^{* 2}$ & 0 & $-1 / 2$ & 0 & 0 \\
\hline Husband's fertility preference squared & $\pi_{h}^{* 2}$ & 0 & $1 / 2(1-\theta)$ & 0 & 0 \\
\hline
\end{tabular}

Using the specific payoffs in Eqs. (10) and (11) in the main text, the general first order conditions for fertility outcomes, and transfers across spouses, are as follows.

Marriage with commitment

Fertility outcome, $q^{\mathrm{C}}$, satisfies the

first order condition:

Transfer, $t^{\mathrm{C}}$ :

$$
\begin{aligned}
& q^{\mathrm{C}}=\frac{1}{2}\left(\pi_{h}^{*}+\pi_{w}^{*}\right)+\varphi^{\prime}\left(q^{\mathrm{C}}\right)-\frac{1}{2} c^{\prime}\left(q^{\mathrm{C}}\right) \\
& t^{\mathrm{C}}=(1-\theta) v_{h}-\theta v_{w}+\left(\theta \delta_{w}-(1-\theta) \delta_{h}\right) \varphi(0)+\frac{1}{2} \theta\left(q^{C}-\pi_{w}^{*}\right)^{2}-\frac{1}{2}(1-\theta)\left(q^{C}-\pi_{h}^{*}\right)^{2}+\frac{\eta_{h}}{2}(1-\theta) \pi_{h}^{* 2}-\frac{\eta_{w}}{2} \theta \pi_{w}^{* 2}+(1-2 \theta) \varphi\left(q^{C}\right)+\theta c(q)
\end{aligned}
$$

Marriage without commitment

Fertility outcome, $q^{\mathrm{NC}}$, satisfies the

first order condition:

$$
c^{\prime}\left(q^{\mathrm{NC}}\right)=\left(2(1-\theta)+\theta \delta_{w}-(1-\theta) \delta_{h}\right) \varphi^{\prime}\left(q^{\mathrm{NC}}\right)+(1-\theta)\left(1-\eta_{h}\right) \pi_{h}^{*}+\left(1-\theta\left(1-\eta_{w}\right)\right) \pi_{w}^{*}+\left((1-\theta) \eta_{h}-\theta \eta_{w}-2(1-\theta)\right) q^{\mathrm{NC}}
$$

Transfer, $t^{\mathrm{NC}}$ :

$$
t^{\mathrm{NC}}=(1-\theta) v_{h}-\theta v_{w}+\left((1-\theta)\left(1-\delta_{h}\right)-\theta \delta_{w}\right) \varphi\left(q^{\mathrm{NC}}\right)-\frac{\left(1-\eta_{h}\right)}{2}(1-\theta)\left(q^{N C}-\pi_{w}^{*}\right)^{2}+\frac{\left(1-\eta_{w}\right)}{2} \theta\left(q^{\mathrm{NC}}-\pi_{w}^{*}\right)^{2}
$$

For the fertility equation, the table reports the coefficients on each spouse's fertility preference in each model of bargaining.

For the transfers equation, we report the coefficients on the divergence between fertility outcomes and fertility preferences of each spouses, and on fertility preferences directly.

On the threat points in marital bargaining, if the relevant outside option is to divorce, $\eta_{h}=\eta_{w}=0$. This characterizes marriage markets among Malays in Malaysia. If the relevant threat point is some non-cooperative outcome within marriage, $\eta_{h}=\eta_{w}=0$. This characterizes marriage markets for the Chinese in Malaysia. 
Fertility Rate

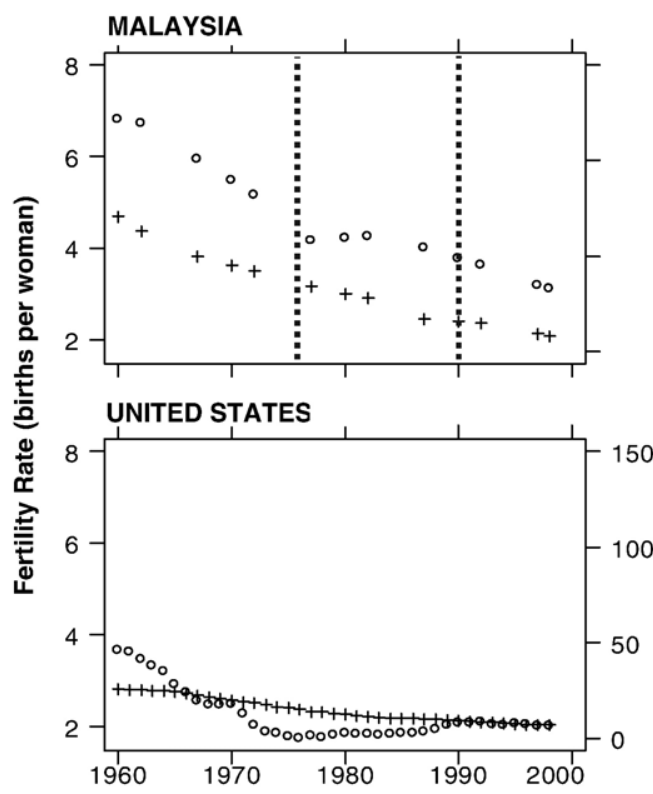

+ Infant Mortality Rate

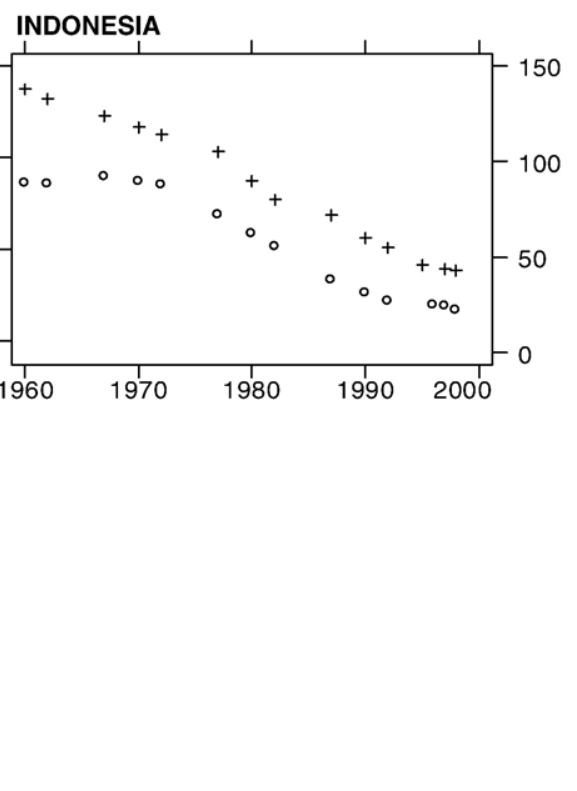

Notes: Data source is the World Development Indicators 2000. The fertility rate is defined as the number of live births per female, and the infant mortality rate is defined as the number of infant deaths per 1000 births. The data for each series are not available in every year for Malaysia and Indonesia. The dashed vertical lines on the figure for Malaysia correspond to the period of study from MFLS-1 in 1976, to MFLS-2 in 1988.

Fig. 1. Aggregate demographic trends.

Malaysia's fertility rate has been in decline since the 1960s, although during the period we focus on between 1976 and 1988, it was relatively stable at around 4 births per female. Within ethnic groups, the fertility rate for Malays fell from 5.9 to 4.5 between 1958 and 1983. This is a smaller fall than for other ethnic groups over the same period, and one that is largely attributed to rising age at marriage for Malay women, from 17 in 1950 to 22 in 1985. For example for the Chinese over the same period, the decline in fertility rates was from 6.5 to 2.7 (Jones, 1994).

An implicit assumption made in the bargaining models in Section 2 is that spouses face no uncertainty over how many of their children survive into adulthood. In support of this note that infant mortality has been in long run decline in Malaysia, and historically, it has also been lower than in many comparable developing countries. For example infant mortality rates in Indonesia have typically been more than double those in Malaysia. Indeed, by the late 1980s, infant mortality in Malaysia was at levels comparable to those in the US in the early 1960 s. $^{20}$

\footnotetext{
${ }^{20}$ Jones (1994) also documents the sharp reduction in child mortality rates that Malaysia experienced during the 1960s. In our data, the number of children ever born has a correlation coefficient of .95 with the number of pregnancies, further suggesting parents face little uncertainty over the likelihood of survival for their children.
}

\subsubsection{Ethnicity and marriage markets}

A key difference between Malays and Chinese in Malaysia lies in how their marriage markets operate. Since the 1940s, Malays have had one of the highest divorce rates in the world (Jones, 1981, 1994). Table 2 compares divorce rates over the period 1965-1985 for Malays in Peninsular Malaysia, for Muslims in Indonesia, and for the United States. ${ }^{21}$

Two points are of note. First, the divorce rate in Malaysia in the 1960s and 1970s is comparable to the divorce rate in the US today. Clearly, divorce is a credible threat among married Malay couples. Second, high divorce rates appear to be a characteristic particular to the ethnic group of Malays, and not a feature of the economic environment faced by Malays in Malaysia. Muslims in Indonesia - who are predominantly ethnically

\footnotetext{
${ }^{21}$ The divorce rate is defined as the number of divorcees per thousand population aged 15 and over. This measure understates the true divorce rate in the US as individuals marry at an older age compared to in Malaysia. Similarly, the measure understates the true divorce rate in Peninsular Malaysia in later periods relative to early periods because the median age at marriage for Malays has been rising. However, as shown in Fig. 2, the comparison across countries remains unchanged if the number of currently married is used as the denominator. The decline in divorce rates among Malays from 1965 to 1985 may be explained by the rise in educational attainment for both men and women in Malaysia, coupled with rising ages at first marriage.
} 
Table 2

Divorce rates 1965-1985

\begin{tabular}{llll}
\hline & $\begin{array}{l}\text { Malays in peninsular } \\
\text { Malaysia }\end{array}$ & $\begin{array}{l}\text { Indonesian } \\
\text { Muslims }\end{array}$ & $\begin{array}{l}\text { United } \\
\text { States }\end{array}$ \\
\hline 1965 & 7.4 & 11 & 3.5 \\
1970 & 6.1 & 5.2 & 4.8 \\
1975 & 5.6 & 4.6 & 6.3 \\
1980 & 3.9 & 2.6 & 6.7 \\
1985 & 2.8 & 1.5 & 6.3 \\
\hline
\end{tabular}

Notes: The source for this table is Jones (1994). The divorce rate is defined as the number of divorcees per thousand of the population aged 15 and over.

Malay - have divorce rates comparable to Malays in Peninsular Malaysia.

Fig. 2 sheds light on the levels of turnover in the Malay marriage market, and how this varies by region. This shows the ratio of divorces to marriages for Malays, by state, for 1950-7 and 1972-6. This divorce propensities in the Malay marriage market increased between the 1950s and 1970s. By the 1970s, these levels of turnover in marriage markets are higher than those ever witnessed in the United States over the past generation.

Two other features of the bargaining models developed also closely approximate how Malay marriage markets operate in practice. First, despite high divorce rates, first marriages are not just trial relationships children are typically born into these marriages. Hence the marital surplus to be bargained over ex post depends on ex ante fertility choices. ${ }^{22}$ Second, ethnographic evidence suggests that both spouses are able to dissolve a marriage. $^{23}$

The fact that divorce is a credible threat among Malays further implies that the allocation of child custody determines spousal payoffs if marital bargaining breaks down. If couples bargain without commitment, the allocation of child custody will therefore in part, determine investments into fertility. A concern for the empirical analysis is that the allocation of child custody varies across households and may be correlated

\footnotetext{
${ }^{22}$ Hirschman and Teerawichitchainan (2003) provide evidence on the determinants of marital dissolution in Malay households using 1970 census data. They show that the timing of first births is a significant determinant of marital dissolution so that the allocation of custody is relevant for divorcing Malay couples.

${ }^{23}$ While official records show that men initiate the majority of divorces, ethnographic evidence suggests that in practice, women typically instigate divorce (Rudie, 1983; Jones, 1981). Malay women have historically had considerable autonomy with regards to marriage partner, household decisions within marriage, and the decision to divorce (Swift, 1965; Kuchiba et al., 1979).
}

with parental fertility preferences. However, in practice, children tend to reside with their mothers, regardless of age or gender (Jones, 1981, 1994). ${ }^{24}$

In contrast to Malays, divorce is extremely rare among the Chinese in Malaysia. As documented by Hirschman and Teerawichitchainan (2003), the probability of divorce in the first 5 years of marriage among Chinese has been less than $2 \%$ for all cohorts married since the 1940s. Not only is this orders of magnitude smaller than among Malays, but also smaller than for any other ethnic group in South East Asia. ${ }^{25}$

\subsubsection{Data and key variables}

We use the Malaysian Family Life Survey (MFLS) for the empirical analysis. This is two-wave household panel, collected in 1976/7 (MFLS-1) and 1988/9 (MFLS-2). The MFLS-1 sample consists of households with an ever-married woman aged 50 or below, and is representative of Peninsular Malaysia in 1976. Both spouses are interviewed in each wave. The survey collects detailed current and retrospective information on fertility preferences, fertility outcomes, individual and household characteristics. The key variables for the analysis are as follows.

\subsubsection{Fertility preferences}

In MFLS-1 both spouses were asked, "suppose you could start your married life all over again and you could decide what children to have. How many children would you want?" We use the response to measure each spouses' desired number of children, $\pi_{i}^{*}$. However, as we discuss in detail later, there are concerns as to whether this is a reliable measure of innate preferences. This is however perhaps the most accurate measure of innate preferences that can ever be expected from survey data. ${ }^{26}$

\footnotetext{
${ }^{24}$ The Malaysian Marriage Survey (1984) reports that 55\% of children involved in divorce reside with their mothers, $19 \%$ stay with their fathers, and $13 \%$ reside with both parents in some form of joint custody (Tan and Jones, 1990). Fathers are required by Islamic law to pay maintenance in divorce. In practice, the incidence of fathers paying is less than universal. Tan and Jones (1990) report 59\% of husbands never pay maintenance.

${ }^{25}$ Similar evidence for later periods on these differences in divorce rates across ethnic groups is presented using alternative data sources in Tan (1988) and Jones (1994).

${ }^{26}$ If the intent of the question was understood and followed by respondents, they should report the number of wanted children, and not the number of expected children. Furthermore, the questionnaire was administered in one of ten languages, further reducing the possibility of misinterpretation. Less than $1 \%$ of households did not respond to the question.
} 


\section{$1950-57$}

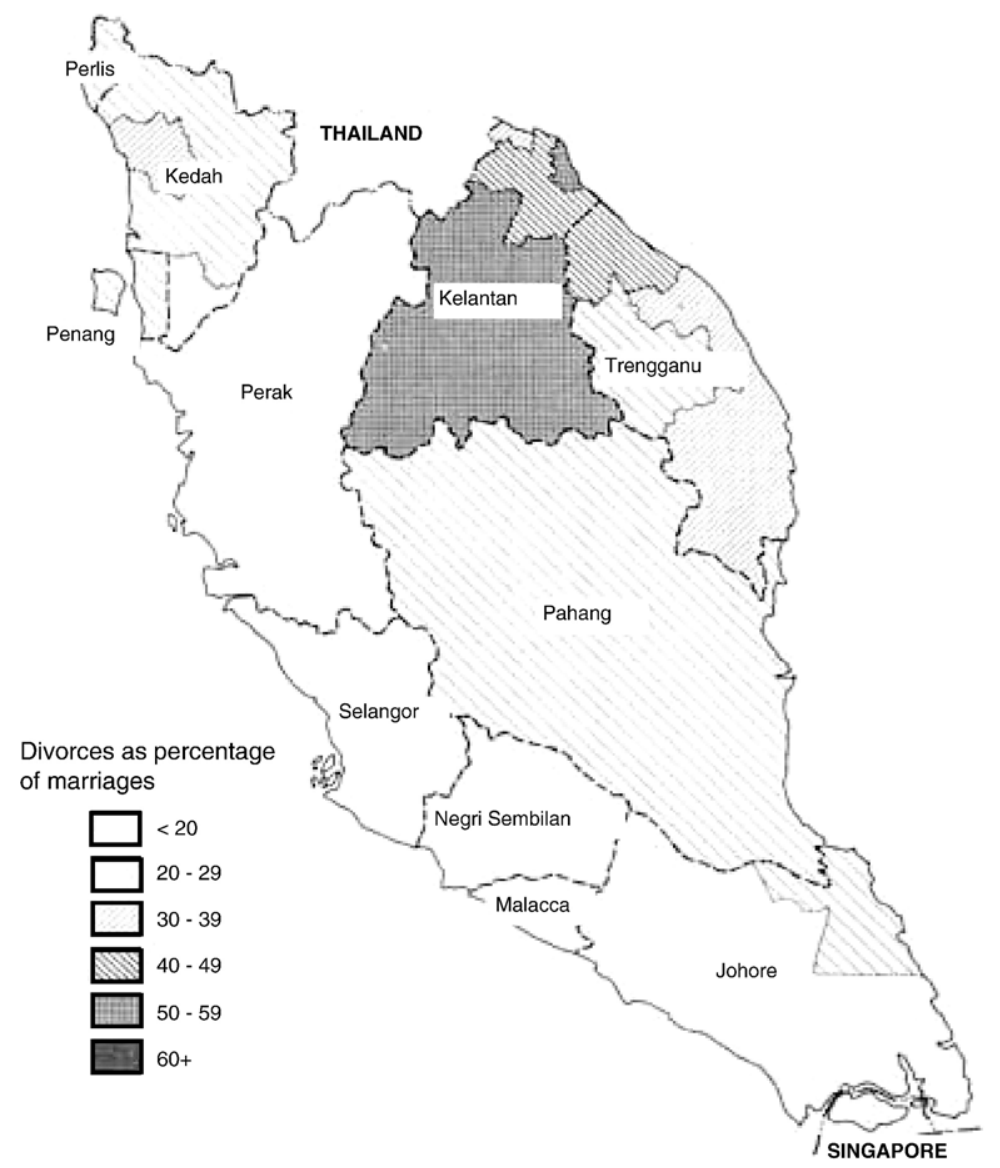

$1970-76$

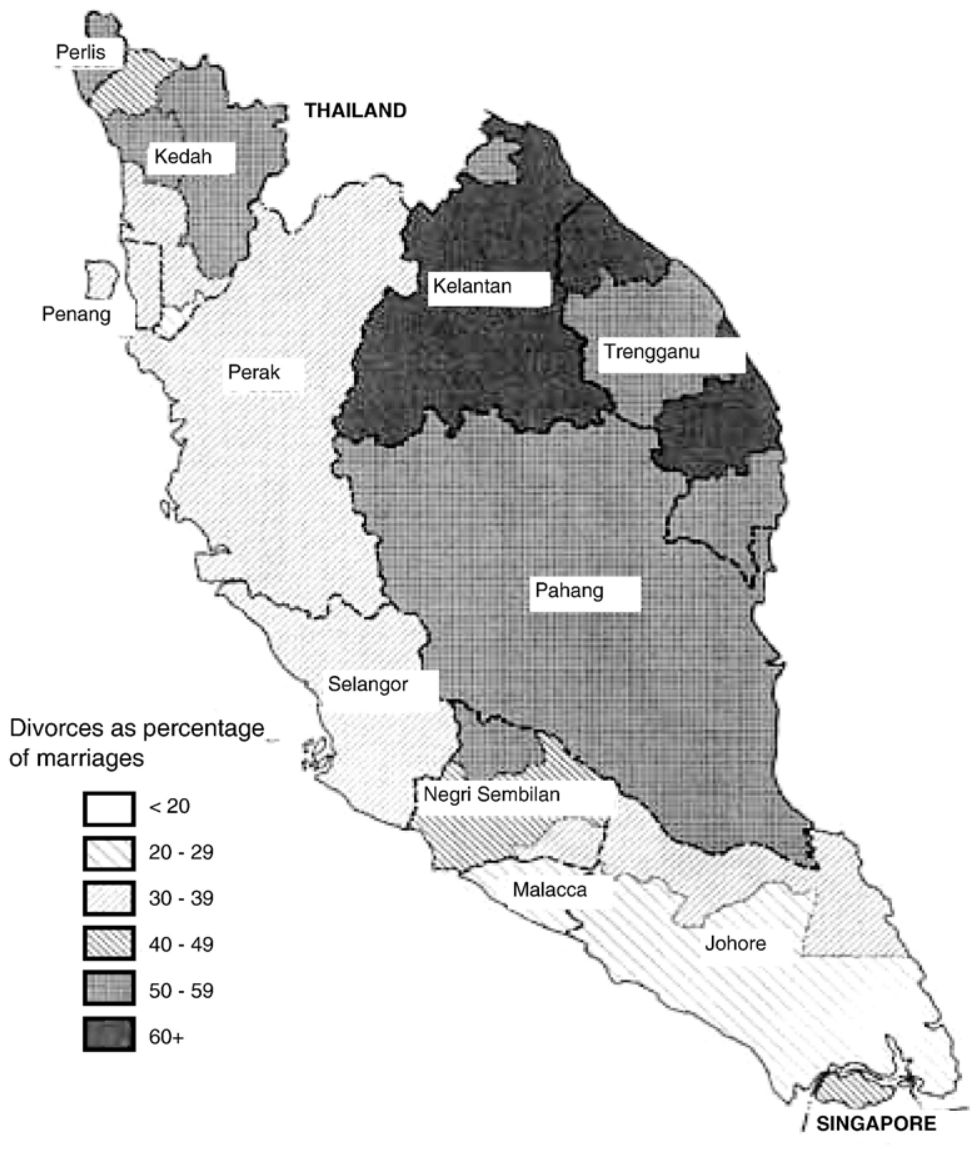

Fig. 2. Ratio of Malay divorces (net of revocations) to marriages, by State in Peninsular Malaysia. Source: Jones (1994). 
Table 3

Descriptive statistics on fertility preferences and fertility outcomes

\begin{tabular}{|c|c|c|c|c|c|c|}
\hline & \multicolumn{3}{|c|}{ Malay households } & \multicolumn{3}{|c|}{ Chinese households } \\
\hline & Husband & Wife & $\begin{array}{l}\text { Test of } \\
\text { equality } \\
\text { ( } p \text {-value) }\end{array}$ & Husband & Wife & $\begin{array}{l}\text { Test of } \\
\text { Equality } \\
\text { ( } p \text {-value) }\end{array}$ \\
\hline \multicolumn{7}{|c|}{ Fertility preferences by ethnicity and gender (mean and $95 \%$ confidence interval) } \\
\hline Number of children desired in total & $\begin{array}{l}4.97 \\
{[4.72,5.22]}\end{array}$ & $\begin{array}{l}4.60 \\
{[4.42,4.77]}\end{array}$ & .0161 & $\begin{array}{l}4.33 \\
{[4.16,4.52]}\end{array}$ & $\begin{array}{l}4.05 \\
{[3.88,4.22]}\end{array}$ & .0249 \\
\hline Number of boys desired & $\begin{array}{l}2.48 \\
{[2.37,2.63]}\end{array}$ & $\begin{array}{l}2.25 \\
{[2.24,2.43]}\end{array}$ & .0114 & $\begin{array}{l}2.27 \\
{[2.15,2.39]}\end{array}$ & $\begin{array}{l}2.14 \\
{[2.03,2.26]}\end{array}$ & .1219 \\
\hline Number of girls desired & $\begin{array}{l}2.16 \\
{[2.03,2.28]}\end{array}$ & $\begin{array}{l}2.20 \\
{[2.10,2.31]}\end{array}$ & .7068 & $\begin{array}{l}1.96 \\
{[1.85,2.07]}\end{array}$ & $\begin{array}{l}1.83 \\
{[1.73,1.92]}\end{array}$ & .0713 \\
\hline \multicolumn{7}{|c|}{ Fertility outcomes by ethnicity (mean and 95\% confidence interval) } \\
\hline Fertility outcome (MFLS-2) & & $\begin{array}{l}6.38 \\
{[6.11,6.64]}\end{array}$ & & & $\begin{array}{l}5.79 \\
{[5.41,6.16]}\end{array}$ & \\
\hline $\begin{array}{l}\text { Number of children } \\
\text { ever born in MFLS-1 }\end{array}$ & & $\begin{array}{l}3.46 \\
{[3.25,3.67]}\end{array}$ & & & $\begin{array}{l}4.15 \\
{[3.85,4.45]}\end{array}$ & \\
\hline
\end{tabular}

Notes: Sample households are those used for the fertility regressions. Tests of equality are across gender, within ethnicity. Tests of equality of means and proportions all have two-sided alternative hypotheses. For all tests, we do not impose the restriction that the samples have the same variance or are paired. All fertility preferences are expressed in MFLS-1. The desired number of boys and girls does not sum to the total number of children desired because spouses were also asked the number of children they wanted whose gender was undecided.

\subsubsection{Fertility outcomes}

We use the number of children alive in MFLS-2 as a measure of the fertility outcome. Hence fertility outcomes are measured 12 years after fertility preferences are expressed. The average age of women in MFLS-2 is 47 years. Census data confirms that $98 \%$ of women this age have completed their fertility period, so that censoring of fertility outcomes is not a major concern. ${ }^{27}$

A more substantive worry is that at the time of MFLS1 , women were in the middle of their fertility period. Hence fertility preferences may be endogenous to the stage of the fertility period the couple are at. This occurs for example if spouses learn the true costs and benefits of children over time. We later address econometric concerns arising from the endogeneity of preferences.

On the other hand, because in the MFLS-1 sample women are already some way into their fertility period, then in line with the model of marital bargaining, some investments into fertility have been sunk, and there is scope for renegotiation over the division of the marital surplus.

The sample of households used for the main analysis are husband and wife pairs that satisfy three criteria (i) both fertility preferences, fertility outcomes, and other variables used in the main analysis are reported;

\footnotetext{
${ }^{27}$ The majority of women in the sample also considered their fertility period over by MFLS-2, either because of menopause or sterilization.
}

(ii) both report being fertile and resident in the household in MFLS-1; (iii) were continuously married between the two waves. This last restriction applies because in the models developed, all couples remain married in equilibrium. Although threat points in marital bargaining influence household outcomes, the theory predicts that no couples actually experience a breakdown in bargaining in equilibrium. Hence it is exactly those households in the data that bargain and allocate the marriage surplus so as to remain married, that the theory applies to. There are 472 Malay couples, and 220 Chinese couples that satisfy these criteria.

\subsection{Descriptives}

\subsubsection{Fertility preferences}

Table 3 presents descriptive statistics on fertility preferences, split by spouse and ethnicity. A striking result that emerges is the degree of conflict over preferences over fertility within couples. Among Malays, husband's desire significantly more children than their wives. This difference is largely driven by husbands desiring more sons than their wives. Overall, around two thirds of Malay couples report disagreements on fertility preferences.

Although Chinese households desire slightly fewer children than do Malays, there remain significant differences in the fertility preferences of husbands and their wives. Unlike for Malays, this difference is driven 
largely by husbands desiring more daughters than their wives. Overall, just over half the Chinese couples report disagreements on fertility preferences.

These significant differences in preferences within households occur despite the fact that these households remain married over the two MFLS waves, and the sample sizes are relatively small. ${ }^{28}$

To see more clearly the extent of conflict over fertility within each household, Fig. 3 graphs for each ethnic group, a two-way frequency distribution for husband and wife's preferences, in couples where there is some disagreement over fertility.

Among Malay households, $44 \%$ differ by at least two children, and $10 \%$ differ by more than four. In Chinese households, although the majority of couples still disagree, the extent of these differences is smaller than in Malay households. Around one third of Chinese households disagree by one child in their preference, one fifth differ by two or more.

\subsubsection{Fertility outcomes}

The remainder of Table 3 presents information on fertility outcomes. Unsurprisingly, the number of children ever born in MFLS-2 is significantly greater than that in MFLS-1, suggesting the fertility period is incomplete at MFLS-1. However, as measured in MFLS-2, fertility outcomes for both ethnic groups are significantly higher than the largest preferences of either spouse. In both Malay and Chinese households, around 1.5 more children are born on average than either spouse reports to be their preferred number 12 years earlier in MFLS-1. This may be indicative of households bargaining without commitment, which under the conditions identified in Result 3, leads to overinvestment into fertility. Alternatively, this may reflect that parents learn the true costs and benefits of children over time, and on average, revise their desires upwards.

However, Table 3 provides two further pieces of evidence that suggest reported preferences do relate to spouses' innate preferences over fertility. First, as spouses have significantly different preferences, they are unlikely to be reporting the expected number of children unless there is a significant degree of asymmetric information in the household.

\footnotetext{
${ }^{28}$ To shed more light on how representative these households are of the total population, we also checked these reported preferences against those from other surveys. The World Fertility Survey was administered to over 6000 households in Malaysia in 1974. Only women were asked to report their fertility preferences however. Malay women reported desiring 4.70 children, Chinese women reported 4.03 children. These are not significantly different from the reports given in MFLS- 1 .
}

Second, spouses' reports bear little relation to the actual number of children present in the household at the time of the report. For example among Malay households, around two thirds of husbands and wives report a preference greater than the number of children they have at the time, around one fifth report desiring strictly fewer children than they have at the time. Among Chinese households, around two fifths of spouses report desiring more children than they have at the time, and one third report desiring strictly fewer children.

\subsection{Empirical method}

The first order conditions for fertility when spouses bargain with commitment, (Eq. (12)), and without commitment, (Eq. (14)), both reduce to the following form;

$$
\begin{aligned}
q\left(\theta, \delta_{h}, \delta_{w}, \eta_{h}, \eta_{w}, q\right)= & \beta_{h}\left(\theta, \delta_{h}, \delta_{w}, \eta_{h}, \eta_{w}\right) \pi_{h}^{*} \\
& +\beta_{w}\left(\theta, \delta_{h}, \delta_{w}, \eta_{h}, \eta_{w}\right) \pi_{w}^{*} .
\end{aligned}
$$

This separates out the determinants of fertility into those relating to each spouse's desired fertility, $\pi_{i}^{*}$, and those arising from other costs and benefits of children, captured in $g($.$) . We estimate the following linear$ regression for the fertility outcome in household $n$ and district $d$;

$$
\begin{aligned}
q_{n d}= & \alpha_{d}+\beta_{h} \pi_{\text {hnd }}^{*}+\beta_{w} \pi_{w n d}^{*}+\gamma_{h} X_{\text {hnd }} \\
& +\gamma_{w} X_{w n d}+\gamma X_{n d}+u_{n d},
\end{aligned}
$$

where $q_{n d}$ is the equilibrium fertility outcome measured in MFLS-2, and $\pi_{\text {ind }}^{*}$ is the fertility preference of spouse $i$ in household $n$ in district $d$ expressed in MFLS-1. $X_{\text {hnd }}, X_{w n d}$ and $X_{n d}$ are characteristics of the husband, wife, and household respectively, measured in MFLS-1, that capture the costs and benefits of children. $\alpha_{d}$ is a district fixed effect. There are 70 districts in Peninsular Malaysia and it is important to control for such regional differences as these may in part capture variations in access to family planning clinics and other resources that stem from public policy, and that drive fertility outcomes.

The parameters of interest are $\beta_{h}$ and $\beta_{w}$. A necessary condition for these to be consistently estimated is that spousal preferences are uncorrelated to the error term, $u_{n d}$. We maintain this assumption for now, and later address econometric concerns arising from there being omitted determinants of fertility that are correlated to fertility preferences, and from preferences being endogenously determined or measured with error. 


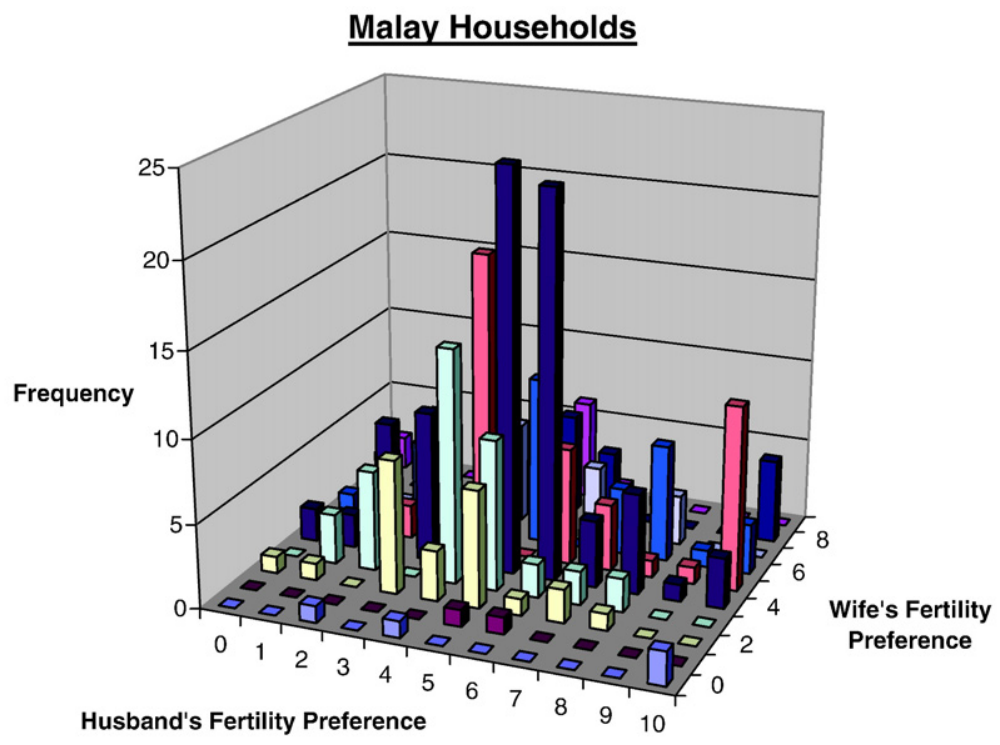

Chinese Households

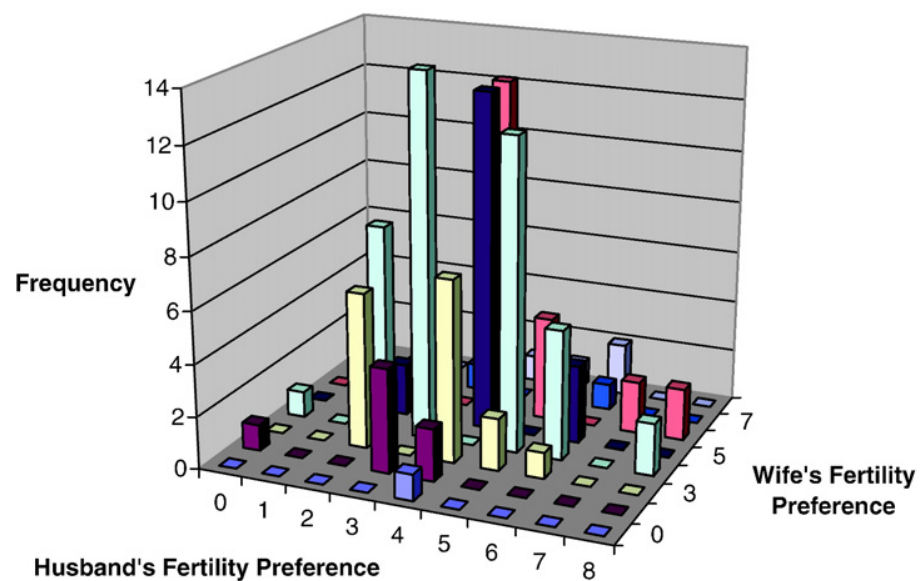

Notes: These distributions are for those households in which there is conflict over fertility preferences. To prevent outliers from distorting the figures, for Malays, the sample includes households in which spouses desired up to 10 children. For Chinese, the sample includes households in which spouses desired up to 8 children.

Fig. 3. Disagreements on fertility preferences.

If spouses bargain with commitment, theory suggests that - (i) both spouses' preferences have some weight in determining fertility outcomes; (ii) the outside option in marital bargaining has no affect on fertility outcomes, and so how fertility preferences translate into fertility outcomes should be the same across Malay and Chinese households; (iii) the distribution of bargaining power within marriage should have no affect on fertility outcomes.

If spouses bargain without commitment, then as emphasized in Section 2 - (i) the pattern of $\left(\beta_{h}, \beta_{w}\right)$ coefficients depend on the relevant threat point in marital bargaining, and therefore will vary across ethnic groups; (ii) the distribution of bargaining power within marriage affects fertility outcomes.

For Malay households, as the threat point in bargaining for Malays is to divorce, both fertility preferences determine the surplus to be bargained over, and through this channel, both preferences determine the fertility outcome. Hence we would expect $\beta_{h}=\beta_{w}$ so both spouses' preferences have equal weight in determining fertility outcomes. 
Table 4

Means and standard deviations for other controls, by ethnicity and gender

\begin{tabular}{|c|c|c|c|c|c|c|}
\hline & \multicolumn{2}{|c|}{ Malay households } & \multicolumn{2}{|c|}{ Chinese households } & \multicolumn{2}{|c|}{$\begin{array}{l}\text { Test of equality within } \\
\text { gender, across ethnicities }\end{array}$} \\
\hline & Husband & Wife & Husband & Wife & $\begin{array}{l}\text { Husbands } \\
\text { ( } p \text {-value) }\end{array}$ & $\begin{array}{l}\text { Wives } \\
\text { ( } p \text {-value) }\end{array}$ \\
\hline Age & $\begin{array}{l}41.32 \\
(10.57)\end{array}$ & $\begin{array}{l}35.25 \\
(8.68)\end{array}$ & $\begin{array}{l}40.29 \\
(9.14)\end{array}$ & $\begin{array}{l}35.45 \\
(7.78)\end{array}$ & .2114 & .7755 \\
\hline Age at marriage & $\begin{array}{l}25.67 \\
(9.54)\end{array}$ & $\begin{array}{l}16.51 \\
(3.09)\end{array}$ & $\begin{array}{l}27.05 \\
(6.97)\end{array}$ & $\begin{array}{l}20.69 \\
(3.57)\end{array}$ & .0615 & .0000 \\
\hline Age menstruation & & $\begin{array}{l}13.44 \\
(1.53)\end{array}$ & & $\begin{array}{l}14.31 \\
(1.74)\end{array}$ & & .0000 \\
\hline Years of schooling & $\begin{array}{l}4.49 \\
(3.27)\end{array}$ & $\begin{array}{l}3.00 \\
(3.21)\end{array}$ & $\begin{array}{l}5.93 \\
(4.04)\end{array}$ & $\begin{array}{l}3.92 \\
(4.15)\end{array}$ & .0000 & .0015 \\
\hline No schooling & $\begin{array}{l}.19 \\
(.39)\end{array}$ & $\begin{array}{l}.42 \\
(.49)\end{array}$ & $\begin{array}{l}.08 \\
(.27)\end{array}$ & $\begin{array}{l}.33 \\
(.48)\end{array}$ & .0000 & .0333 \\
\hline Some primary schooling & $\begin{array}{l}.42 \\
(.49)\end{array}$ & $\begin{array}{l}.31 \\
(.46)\end{array}$ & $\begin{array}{l}.40 \\
(.49)\end{array}$ & $\begin{array}{l}.34 \\
(.48)\end{array}$ & .7041 & .3811 \\
\hline Completed primary school & $\begin{array}{l}.40 \\
(.49)\end{array}$ & $\begin{array}{l}.28 \\
(.45)\end{array}$ & $\begin{array}{l}.52 \\
(.50)\end{array}$ & $\begin{array}{l}.33 \\
(.47)\end{array}$ & .0019 & .1894 \\
\hline Non-earned income (monthly) & $\begin{array}{l}297 \\
(1464)\end{array}$ & $\begin{array}{l}219 \\
(1174)\end{array}$ & $\begin{array}{l}227 \\
(1178)\end{array}$ & $\begin{array}{l}902 \\
(160)\end{array}$ & .5296 & .0000 \\
\hline Employed (yes=1) & $\begin{array}{l}.96 \\
(.19)\end{array}$ & $\begin{array}{l}.60 \\
(.49)\end{array}$ & $\begin{array}{l}.98 \\
(.15)\end{array}$ & $\begin{array}{l}.60 \\
(.49)\end{array}$ & .3157 & .9854 \\
\hline Water supply (yes=1) & & $\begin{array}{l}.26 \\
(.44)\end{array}$ & & $\begin{array}{l}.65 \\
(.48)\end{array}$ & & .0000 \\
\hline Electric supply (yes=1) & & $\begin{array}{l}.34 \\
(.47)\end{array}$ & & $\begin{array}{l}.72 \\
(.49)\end{array}$ & & .0000 \\
\hline
\end{tabular}

Notes: Sample sizes are the same as those used for the fertility regressions. Two outliers are dropped when calculating the non earned income of wives in Chinese households. Tests of equality are across ethnicity, within gender. Tests of equality of means and proportions all have two-sided alternative hypotheses. For all tests, we do not impose the restriction that the samples have the same variance or are paired. Completed primary school corresponds to 6 or more years of schooling. All monetary variables are measured in 1986 Malaysian Ringgit.

For Chinese households, as the threat point in bargaining is non-cooperation within marriage, neither fertility preference determines the surplus to be bargained over. As only the wife contributes to investments into fertility, only her preference then determines the fertility outcome. Hence we expect $\beta_{h}=0$ and $\beta_{w}>0 .{ }^{29}$

The characteristics controlled for in $X_{\text {wnd }}$ include the wife's age, her age at marriage, and the age at which menstruation started. These capture the stage of the fertility period the wife is at. We also control for the wife's schooling and monthly non-earned income. These capture her opportunity cost of having children. Other things equal, womens' education reduces fertility through a number of channels — by raising the opportunity cost of time, reducing infant mortality, increasing knowledge and use of contraception, or by

\footnotetext{
${ }^{29}$ In a more general setting, as long as the wife's investment into fertility is relatively more important than her husbands, the implication is that her preference matters more than her husband's for fertility outcomes, so that $\beta_{w} \geq \beta_{h}>0$.
}

reducing the desired number of children. The empirical results will shed some light on the interplay between women's education, fertility preferences, and fertility outcomes.

Characteristics of the husband controlled for, $X_{h n d}$, include his schooling, non-earned income, and employment status. These capture the husband's opportunity costs of raising children. Finally we control for household wealth using information on whether the household has its own supply of running water and electricity. $A$ priori, wealth has ambiguous effects on fertility as income and substitution effects move in opposite directions when children are a normal good.

Table 4 presents summary statistics for these controls, by ethnicity and gender. Consistent with earlier literature, Malays tend to marry earlier than Chinese, have fewer years of schooling and are less wealthy. Malay and Chinese women are equally likely to participate in the labor force, although Chinese women have significantly greater amounts of non-earned income.

Both ethnic groups use similar forms of contraception as reported in MFLS1. Among Malays, 74\% 
report using no form of contraception, and 9\% report using the contraceptive pill. The corresponding figures among Chinese households are $49 \%$ and $17 \%$ respectively. These forms of birth control are more likely to lead to problems of non-commitment and renegotiation than other forms of control, such as injectibles and sterilization, that can be committed to.

In Sections 4.1 and 4.2 we present estimates of the baseline specification (Eq. (17)) for each ethnic group. We then explore some other implications of the theory on the relation between fertility preferences and fertility outcomes in Section 4.3. In Section 4.4 we address econometric concerns.

\section{Results}

\subsection{Malay households}

Table 5 presents OLS estimates of the baseline specification (Eq. (17)) for Malay households. We later also estimate (Eq. (17)) using ordered probit and negative binomial models to account for the discrete nature of fertility outcomes. Throughout we report robust standard errors, and to ease exposition, we report only the parameters of interest, $\left(\beta_{h}, \beta_{w}\right)$ for each specification. In Table A1 we provide the coefficients on the full set of controls.

Column 1 of Table 5 estimates Eq. (17) only controlling for spouses' fertility preferences, $\pi_{i n d}^{*}$, and district fixed effects. Both preferences have a positive and significant effect on the fertility outcome. At the foot of the table we report the $p$-value on the test of the hypothesis $\beta_{h}=\beta_{w}$. We cannot reject the hypothesis that husband and wife's preferences have an equal effect on fertility outcomes for Malay households.

Column 2 introduces controls for the stage of the fertility period the wife is at. Both spouse's preferences continue to have positive, significant, and equal effects on fertility outcomes. In Column 3 we control for the characteristics of the wife that capture her opportunity cost of having children. The effect of each spouses' preferences on fertility outcomes remains unchanged. The next column introduces the same characteristics for the husband, and also controls for measures of household wealth. The previous results are robust to controlling for this full set of characteristics.

The pattern of coefficients on these other controls is also informative, and reported in full in Column 1 of Table A1. Malay households in which women are older, married earlier, and started menstruating later, have significantly more children as expected. Wives with only some primary education have fewer children, although this effect is somewhat weak, being significant only at the $10 \%$ level. There is a negative and insignificant relationship between fertility and education for women that have completed primary education. These results are broadly in line with the existing literature that documents a negative correlation between

Table 5

Fertility regressions, Malay households

\begin{tabular}{|c|c|c|c|c|c|c|}
\hline & \multicolumn{6}{|c|}{ Malay Households } \\
\hline & (1) Baseline & $\begin{array}{l}\text { (2) Fertility } \\
\text { Period }\end{array}$ & $\begin{array}{l}\text { (3) Wife's } \\
\text { Characteristics }\end{array}$ & $\begin{array}{l}\text { (4) All } \\
\text { Controls }\end{array}$ & $\begin{array}{l}\text { (5) Ordered } \\
\text { Probit }\end{array}$ & $\begin{array}{l}\text { (6) Negative } \\
\text { Binomial }\end{array}$ \\
\hline Husband's desired number of children & $\begin{array}{l}.145^{* * *} \\
(.055)\end{array}$ & $\begin{array}{l}.140^{* * *} \\
(.057)\end{array}$ & $\begin{array}{l}.140 * * * \\
(.057)\end{array}$ & $\begin{array}{l}.123 * * \\
(.058)\end{array}$ & $\begin{array}{l}.053 * * * \\
(.023)\end{array}$ & $\begin{array}{l}.023 * * * \\
(.008)\end{array}$ \\
\hline Wife's desired number of children & $\begin{array}{l}.164^{* *} \\
(.066)\end{array}$ & $\begin{array}{l}.135^{* *} \\
(.068)\end{array}$ & $\begin{array}{l}.131^{* *} \\
(.068)\end{array}$ & $\begin{array}{l}.155^{* *} \\
(.066)\end{array}$ & $\begin{array}{l}.069^{* * *} \\
(.027)\end{array}$ & $\begin{array}{l}.022^{* *} \\
(.010)\end{array}$ \\
\hline Control for Fertility period & No & Yes & Yes & Yes & Yes & Yes \\
\hline Control for Wife's Characteristics & No & No & Yes & Yes & Yes & Yes \\
\hline $\begin{array}{l}\text { Control for Husband's Characterisctics } \\
\text { and Household Wealth }\end{array}$ & No & No & No & Yes & Yes & Yes \\
\hline District Fixed Effects & Yes & Yes & Yes & Yes & Yes & Yes \\
\hline Test (p_value): $\beta_{h}=\beta_{w}$ & .8428 & .9598 & .9298 & .7584 & .7139 & .9574 \\
\hline Adjusted R_squared & .1263 & .2012 & .1973 & .2593 & - & - \\
\hline Observations & 472 & 472 & 472 & 472 & 472 & 472 \\
\hline
\end{tabular}

Dependent variable $=$ Fertility outcome (number of children ever born, measured in MFLS-2) Robust standard errors reported in parentheses.

Notes: ${ }^{* *}$ denotes significance at $1 \%,{ }^{* *}$ at $5 \%$, and $*$ at $10 \%$. Robust standard errors are reported throughout. OLS estimates are presented in Columns 1 to 4 . Controls in Column 1 are both spouses' desired number of children and district fixed effects. Column 2 additionally controls for the wife's age, her age at marriage, and the age at which menstruation started. Column 3 additionally controls for whether the wife has some primary education, whether she has completed primary education, and her monthly non-earned income. Columns 4 to 6 all additionally control for the husbands education, non-earned income, employment status, and whether the household has a supply of electricity and water. Completed primary school corresponds to 6 or more years of schooling. The omitted education category is no schooling. 
education and fertility for women with little education and the weaker relationship among more educated women. ${ }^{30}$

However, a concern remains that fertility preferences are themselves determined by education. As a check on this, we re-estimated the specification in Column 4 without controlling for preferences. The estimated coefficients on whether the wife has some primary education, or whether she has completed primary education, remain almost identical to those when preferences are controlled for, as reported in Column 2 of Table A1. The results suggest that in this sample of households, fertility preferences and education are not much correlated. ${ }^{31}$

Households in which husbands have higher nonearned income and are employed, have significantly higher levels of fertility. More educated husbands have significantly more children, although this is likely to be picking up an effect of household income on fertility. ${ }^{32}$ Finally, the wife's non-earned income and whether the household has its own supply of running water do not predict fertility outcomes. If these controls capture wealth effects, they may be insignificant because of offsetting income and substitution effects.

We also estimated the baseline specification and additionally control for the employment status and nonearned income of husbands in MFLS-2. ${ }^{33}$ Column 3 of Table A1 shows that among Malay households, those in which husbands are employed in MFLS-2 have significantly higher fertility levels, although there is no effect of the husband's non-earned income. The effects of husband and wives preferences continue to be the same as in the baseline specification.

The remaining Columns in Table 5 use estimation techniques that take account of the discrete nature of the dependent variable. We first estimate Eq. (17) using an ordered probit model. This model assumes fertility outcomes are driven by some underlying continuous process so that as each threshold in the continuous

\footnotetext{
${ }^{30}$ DaVanzo et al. (2003) also report a weak relation between women's education and fertility in the MFLS data.

${ }^{31}$ In fact the sample correlation between female years of schooling and fertility preferences is only -.1270 .

${ }^{32}$ If husband's earnings are also controlled for, the effect of husband's education becomes insignificant. Both preferences continue to have positive, significant, and equal effects on fertility in this specification (not reported).

${ }^{33}$ Among Malays, $77 \%$ of husbands are employed over the two waves, and $56 \%$ of wives are. The corresponding figures for the Chinese are $78 \%$ and $57 \%$. The simple correlation coefficients between husband and wives non-earned income, earned income (both in MFLS-1 and MFLS-2), fertility preferences, and fertility outcomes are all less than .3 in absolute value. This is true for both Malay and Chinese households.
}

process is crossed, an additional child is born. A second approach is to use a negative binomial model. This treats fertility outcomes as being the result of an underlying point process. ${ }^{34}$ Columns 5 and 6 show the main results on the effects of spousal fertility preferences on fertility outcomes, to be robust to these alternative models. As expected, once the discreteness of the dependent variable is accounted for, the $t$-ratios on the estimated coefficients are larger than when the model is estimated using OLS.

To summarize, in Malay households the fertility preferences of husband's and wives have positive, significant, and equal effects on fertility outcomes. The effects of preferences are quantitatively large. The specification in Column 4 implies a one standard deviation in a wife's fertility preference leads to .25 more children being ever born, other things equal. The magnitude of this effect is for example just under half as large as the effect of the wife having some primary education.

\subsection{Chinese households}

An analogous set of specifications for Chinese households are presented in Table 6. In Column 1 only each spouse's fertility preference and district fixed effects are controlled for. Both preferences have a significant and positive effect on fertility outcomes. However, this result is not robust. In Column 2, once we add controls for the stage of the fertility period the wife is at, husbands preferences no longer have any effect on fertility outcomes. In contrast, wives preferences are positively and significantly related to fertility outcomes. This result remains robust to introducing additional controls into the fertility equation.

In particular, adding controls for the wife's characteristics, husband's characteristics, and household wealth, it remains the case that only the wife's fertility preference has any significant effect on fertility outcomes. Moreover, the magnitude of the estimated effect of wives preferences remains relatively stable across the OLS specifications in Columns 2 to 4 . Again this effect is quantitatively large. The specification in Column 4 implies a one standard deviation in a wife's fertility preference leads to .39 more children being ever born, other things equal. As in Malay households, the magnitude of this effect is just under half as large as the effect of the wife having some primary education.

\footnotetext{
${ }^{34}$ The negative binomial model accounts for overdispersion in the dependent and is typically interpreted as allowing for heterogeneity across households (Cameron and Trivedi, 1998). In this data overdispersion does not arise because of excess zeroes - less than $1 \%$ of households have zero children.
} 
Table 6

Fertility regressions, Chinese households

\begin{tabular}{|c|c|c|c|c|c|c|}
\hline & \multicolumn{6}{|c|}{ Chinese households } \\
\hline & $\begin{array}{l}\text { (1) } \\
\text { Baseline }\end{array}$ & $\begin{array}{l}\text { (2) Fertility } \\
\text { period }\end{array}$ & $\begin{array}{l}\text { (3) Wife's } \\
\text { characteristics }\end{array}$ & $\begin{array}{l}\text { (4) All } \\
\text { controls }\end{array}$ & $\begin{array}{l}\text { (5) Ordered } \\
\text { probit }\end{array}$ & $\begin{array}{l}\text { (6) Negative } \\
\text { binomial }\end{array}$ \\
\hline \multirow{2}{*}{$\begin{array}{l}\text { Husband's desired } \\
\text { number of children }\end{array}$} & $.361 * * *$ & .051 & -.010 & .000 & .019 & .000 \\
\hline & $(.143)$ & $(.134)$ & $(.131)$ & $(.137)$ & $(.080)$ & $(.019)$ \\
\hline \multirow{2}{*}{$\begin{array}{l}\text { Wife's desired number } \\
\text { of children }\end{array}$} & $.721 * * *$ & $.388 * * *$ & $.350 * * *$ & $.298^{* *}$ & $.225^{* * *}$ & $.051^{* * *}$ \\
\hline & $(.1500)$ & $(.115)$ & $(.116)$ & $(.123)$ & $(0.70)$ & $(0.17)$ \\
\hline Control for fertility period & No & Yes & Yes & Yes & Yes & Yes \\
\hline Control for wife's characteristics & No & No & Yes & Yes & Yes & Yes \\
\hline $\begin{array}{l}\text { Control for husbands } \\
\text { characteristics and } \\
\text { household wealth }\end{array}$ & No & No & No & Yes & Yes & Yes \\
\hline District fixed effects & Yes & Yes & Yes & Yes & Yes & Yes \\
\hline Test ( $p$-value): $\beta_{h}=\beta_{w}$ & .1479 & .1009 & .0726 & .1558 & .0847 & .0691 \\
\hline Adjusted $R$-squared & .3750 & .5809 & .5936 & .5995 & - & - \\
\hline Observations & 220 & 220 & 220 & 220 & 220 & 220 \\
\hline
\end{tabular}

Dependent variable $=$ Fertility outcome (number of children ever born, measured in MFLS-2) Robust standard errors reported in parentheses.

Notes: $* * *$ denotes significance at $1 \%, * *$ at $5 \%$, and $*$ at $10 \%$. Robust standard errors are reported throughout. OLS estimates are presented in Columns 1 to 4 . Controls in Column 1 are both spouses' desired number of children and district fixed effects. Column 2 additionally controls for the wife's age, her age at marriage, and the age at which menstruation started. Column 3 additionally controls for whether the wife has some primary education, whether she has completed primary education, and her monthly non-earned income. Columns 4 to 6 all additionally control for the husbands education, non-earned income, employment status, and whether the household has a supply of electricity and water. Completed primary school corresponds to 6 or more years of schooling. The omitted education category is no schooling.

The results in Columns 5 and 6 show that when explicit account is taken of the discrete nature of the dependent variable, it is again only the wife's fertility preference that determines fertility outcomes in Chinese households.

The conclusion that husbands matter less for fertility outcomes in Chinese than Malay households is reinforced by the pattern of other coefficients, as reported in Column 4 of Table A1. While the wife's characteristics such as her age, age at marriage, and nonearned income, affect fertility in the expected direction, husband's education, non-earned income and employment status are not significant determinants of fertility in Chinese households.

The relation between wives' education and fertility outcomes is also stronger among Chinese than Malay households. Among Chinese couples, if the wife has some primary education, fertility is predicted to be significantly lower. The magnitude of this effect is larger in absolute value than for Malays and estimated with greater precision. Moreover, if the wife has completed primary education, the couple is predicted to have one less child than if the wife has no years of schooling.

To shed light on the relation between fertility preferences and education, we re-estimate the specification in Column 4 of Table 6, excluding fertility preferences. As reported in Column 5 of Table A1, the effects of wife's education then become marginally stronger.
However, husband's characteristics continue to have no effect on fertility outcomes. ${ }^{35}$

When we additionally control for the employment status and non-earned income of husbands in MFLS-2, the result in Column 6 of Table A1 is consistent with the earlier findings that husband's characteristics are not significant predictors of fertility outcomes. Again, only the fertility preferences of wives determine fertility outcomes. Husband's fertility preferences are not significant, and the point estimate is close to zero. ${ }^{36}$

To summarize, in Chinese households, only the fertility preferences of wives have any effect on fertility outcomes. The effect of wives' preferences is quantitatively large. Husbands' fertility preferences, and characteristics in

\footnotetext{
${ }^{35}$ When husband's earned income, which is potentially endogenous, is included in the full specification, the coefficient on husband's preferences remains insignificant. The coefficient on the wife's preference rises to .34 . The p-value on the null hypothesis that these are equal is .07 .

${ }^{36}$ We also estimated the baseline specification including the husband's earned income both at MFLS- 1 and MFLS-2. This captures both income and substitution effects of earned income on fertility outcomes. For Malay households, those in which the husband has higher income in MFLS-2 have significantly lower fertility outcomes. Husband's income in MFLS-1 is not significant. Among Chinese households, MFLS-1 income significantly reduces fertility outcomes and MFLS-2 income is positive but not significant at conventional levels. The results suggest the magnitude of the income and substitution effects of husband's earned income are different in Malay and Chinese households.
} 
Table 7

Further implications

\begin{tabular}{clll}
\hline & $\begin{array}{l}\text { Malay } \\
\text { households }\end{array}$ & & $\begin{array}{l}\text { Chinese } \\
\text { households }\end{array}$ \\
\cline { 2 - 2 } & $(1 \mathrm{a})$ & & $(1 \mathrm{~b})$ \\
\hline Husband's desired & .055 & -.060 \\
number of children & $(.065)$ & & $(.147)$ \\
Interaction with whether & $.317^{* * *}$ & .718 \\
husband inherits any land & $(.130)$ & & $(.484)$ \\
Wife's desired & $.214^{* * *}$ & $.328^{* * *}$ \\
number of children & $(.071)$ & $(.121)$ \\
Interaction with whether & $-.508^{* *}$ & .305 \\
husband inherits any land & $(.216)$ & & $(.472)$ \\
All baseline controls & Yes & Yes \\
District fixed effects & Yes & Yes \\
Adjusted $R$-squared & .2481 & .5988 \\
Observations & 472 & 220
\end{tabular}

Dependent variable $=$ Fertility outcome (number of children ever born, measured in MFLS-2) Robust standard errors reported in parentheses.

Notes: ${ }^{* * *}$ denotes significance at $1 \%,{ }^{* *}$ at $5 \%$, and $*$ at $10 \%$. Robust standard errors are calculated throughout. The full set of controls as in Tables 5 and 6 are included throughout.

general, have little or no predictive power in explaining fertility outcomes among Chinese households.

In all specifications, the point estimate on husband's preferences is itself close to zero, so that part of the reason why husband's preferences have no significant effect is because the magnitude of any true effect is small. Although $\beta_{h}$ is not estimated with the same precision as in Malay households, this is partly a result, as shown in Table 3, of there being less variation in preferences among Chinese than Malay households. This lack of variation is not however driving the results - wives' preferences in Chinese households have a positive and robust effect on fertility outcomes across all the specifications estimated. What makes the Chinese results more remarkable is that, as reported in the descriptive evidence in Table 3, there is relatively less conflict over fertility in Chinese households than Malay households. This may have led to the false expectation that both spouses influence fertility outcomes. In fact, only the preferences of wives have an effect.

\subsection{Further implications}

The fact that in Malay households, both spouses' fertility preferences have an equal, positive, and significant effect on fertility outcomes, is consistent with both models of household bargaining developed in Section 2. In contrast, for Chinese households, as only wife's preferences determine fertility outcomes, this behavior can only be reconciled with a model of bargaining without commitment. This leads to one of two conclusions.

First, it may be that Malay households can bargain with commitment and Chinese households cannot. This interpretation lacks intuitive appeal if we view the ability of households to commit or not in marital bargains as a fundamental characteristic underlying household behavior, and not something that some households can do, and others cannot. A second interpretation is that all households bargain without commitment. The variation in outcomes across households is then explained by differences in threat points in marital bargaining across ethnic groups.

To explore these interpretations further, we note that if couples bargain with commitment, the effect of spousal preferences should not vary with the distribution of bargaining power. To proxy the distribution of bargaining power we use information on inheritance. In particular we define a dummy equal to one if the husband has inherited any land from his family, and zero otherwise. Unlike other potential proxies for bargaining power, such as education, this is plausibly less correlated with fertility preferences themselves. In Malay households, just over $20 \%$ of husbands have inherited some land. This figure is $10 \%$ in Chinese households. We interact the dummy for the husband having inherited any land, with each spouse's fertility preference in specification (17). We continue to control for the full set of covariates and district fixed effects.

The results for Malay households are reported in Column 1a of Table 7. The husband's fertility preference is a significant determinant of fertility outcomes when he has greater bargaining power within the household, all else equal. The wife's fertility preference still has a significant effect on fertility outcomes, but the effect of her preference is significantly lower if the husband has more bargaining power, other things equal.

Column $1 \mathrm{~b}$ reports the results for Chinese households. Among those couples, the distribution of bargaining power appears to play no role in determining how spouses' fertility preferences translate into fertility outcomes. In line with the baseline results in Table 6, it remains true that only the wife's fertility preference is a significant predictor of fertility outcomes. ${ }^{37}$

\subsection{Econometric concerns}

We now address econometric concerns arising from the estimation of (17). These concerns obviously apply

\footnotetext{
${ }^{37}$ Among Malay households there is no direct effect on fertility of the husband inheriting land. Among Chinese households, the inheritance of land by husbands reduces fertility outcomes, other things equal.
} 
Table 8

Descriptive Statistics on Preferences for Additional Children

\begin{tabular}{|c|c|c|c|c|c|c|}
\hline & \multicolumn{3}{|c|}{ Malay households } & \multicolumn{3}{|c|}{ Chinese households } \\
\hline & Husband & Wife & $\begin{array}{l}\text { Test of equality } \\
\text { ( } p \text {-value) }\end{array}$ & Husband & Wife & $\begin{array}{l}\text { Test of equality } \\
\text { (p-value) }\end{array}$ \\
\hline \multicolumn{7}{|c|}{ Fertility preferences by ethnicity and gender (mean and $95 \%$ confidence interval) } \\
\hline Desire more children? $($ yes $=1)$ & $\begin{array}{l}.517 \\
{[.472, .562]}\end{array}$ & $\begin{array}{l}.483 \\
{[.438, .528]}\end{array}$ & .1409 & $\begin{array}{l}.255 \\
{[.197, .313]}\end{array}$ & $\begin{array}{l}.286 \\
{[.226, .347]}\end{array}$ & .2094 \\
\hline Number of additional children desired & $\begin{array}{l}3.31 \\
{[3.06,3.57]}\end{array}$ & $\begin{array}{l}3.05 \\
{[2.81,3.28]}\end{array}$ & .1280 & $\begin{array}{l}2.09 \\
{[1.73,2.45]}\end{array}$ & $\begin{array}{l}1.75 \\
{[1.52,1.97]}\end{array}$ & .1062 \\
\hline \multicolumn{7}{|c|}{ Additional number of children born between MFLS-1 and MFLS-2 (mean and 95\% confidence interval) } \\
\hline Both spouses desire additional children & & $\begin{array}{l}2.84 \\
{[2.58,3.10]}\end{array}$ & & & $\begin{array}{l}1.57 \\
{[1.25,1.88]}\end{array}$ & \\
\hline One spouse desires additional children & & $\begin{array}{l}2.90 \\
{[2.68,3.12]}\end{array}$ & & & $\begin{array}{l}1.77 \\
{[1.40,2.15]}\end{array}$ & \\
\hline Neither spouse desires additional children & & $\begin{array}{l}2.98 \\
{[2.62,3.33]}\end{array}$ & & & $\begin{array}{l}2.34 \\
{[1.81,2.87]}\end{array}$ & \\
\hline
\end{tabular}

Notes: Sample households are those used for the fertility regressions. Tests of equality are across gender, within ethnicity. Tests of equality of means and proportions all have two-sided alternative hypotheses. For all tests, we do not impose the restriction that the samples have the same variance or are paired. All fertility preferences are expressed in MFLS-1. Only those spouses that said they desired additional children were asked to report the number of additional children they desired. For all others, no additional children were desired.

equally to Malay and Chinese households. However due to limited sample sizes in the MFLS data, and because some of the concerns are addressed exploiting additional information in the data, we are able to only focus on Malay households.

\subsubsection{Omitted variables}

There may be unobserved (to the econometrician) household specific characteristics that determine both fertility preferences and outcomes. These may for example relate to the costs of having children such as local prices of child related goods, the support network available to the household, or the household's permanent income.

The error term in Eq. (17) can then be written as $u_{n d}=\varepsilon_{n}+\varepsilon_{n d}$, where $\varepsilon_{n}$ is the unobserved household determinant of fertility and is correlated to spouses' preferences, and $\varepsilon_{n d}$ is a classical disturbance term. Omitting $\varepsilon_{n}$ in Eq. (17) then leads to inconsistent estimates of $\left(\beta_{h}, \beta_{w}\right)$.

If $\varepsilon_{n}$ is time invariant, consistent estimates may be recovered by applying a transformation to Eq. (17) analogous to first-differencing. Denote those variables measured in the first wave of data, MFLS-1, with a superscript of one, and those measured in MFLS-2 with a superscript of two. Hence $\Delta_{q n d}=\left(q_{n d}^{2}-q_{n d}^{1}\right)$ denotes the additional number of children produced between the two waves. Consistent estimates can then be recovered by estimating the following specification;

$$
\begin{aligned}
\Delta q_{n d}= & \beta_{h} \Delta \pi_{h n d}^{*}+\beta_{w} \Delta \pi_{w n d}^{*}+\gamma_{h} \Delta X_{h n d} \\
& +\gamma_{w} \Delta X_{h n d}+\gamma \Delta X_{n d}+\Delta u_{n d}
\end{aligned}
$$

where the error term $\Delta u_{n d}=\Delta \varepsilon_{n d}$ is uncorrelated to fertility preferences. To implement this approach, we take the following steps. We use information on each spouses desired number of additional children, to proxy for $\Delta \pi_{i n d}^{*}$, the change in the desired number of children over the two waves of data. ${ }^{38}$ We continue to control for the same characteristics as in Eq. (17), as these are correlated to changes in household determinants of fertility. We also include district fixed effects to control for spacial variation in infrastructure and public services that drive fertility. Finally, we report OLS estimates for Eq. (18). The results are however qualitatively unchanged if an ordered probit or negative binomial model is estimated instead.

Only those spouses that said they wanted additional children in MFLS-1 were asked to report the number of additional children they desired. For all others, no additional children were desired. Of the 472 Malay households in our sample, 177 have both spouses desiring additional children. ${ }^{39}$

Table 8 presents descriptive evidence by ethnicity and spouse on whether more children are desired, the additional number of children desired conditional on wanting more children, and the actual number of additional children born between the two waves. On

\footnotetext{
38 In MFLS-1 respondents were asked, "would you personally like to have any more children than the number you have now?", and if yes, "how many more children do you want?".

${ }^{39}$ Only 44 Chinese couples have both spouses desiring additional children.
} 
Table 9

Econometric concerns, Malay households

\begin{tabular}{|c|c|c|c|c|c|}
\hline & \multirow{2}{*}{\multicolumn{2}{|c|}{$\begin{array}{l}\text { Additional number of children born } \\
\text { between MFLS- } 1 \text { and MFLS- } 2\end{array}$}} & \multicolumn{3}{|l|}{ Instrumental variables } \\
\hline & & & \multicolumn{2}{|l|}{ First stage } & \multirow{2}{*}{$\begin{array}{l}\text { Second stage } \\
\text { Fertility Outcome } \\
\text { (MFLS-2) }\end{array}$} \\
\hline & $\begin{array}{l}\text { Both want more } \\
\text { children }\end{array}$ & $\begin{array}{l}\text { At least one wants } \\
\text { more children }\end{array}$ & $\begin{array}{l}\text { Husband's desired } \\
\text { number of children }\end{array}$ & $\begin{array}{l}\text { Wife's desired } \\
\text { number of children }\end{array}$ & \\
\hline & (1) & (2) & (3a) & $(3 b)$ & (4) \\
\hline $\begin{array}{l}\text { Husband's desired number of } \\
\text { additional children }\end{array}$ & $\begin{array}{l}.106^{*} \\
(.064)\end{array}$ & $\begin{array}{l}.110^{*} \\
(.062)\end{array}$ & & & \\
\hline $\begin{array}{l}\text { Wife's desired number of } \\
\text { additional children }\end{array}$ & $\begin{array}{l}.186^{* *} \\
(.086)\end{array}$ & $\begin{array}{l}.141^{* *} \\
(.073)\end{array}$ & & & \\
\hline $\begin{array}{l}\text { Husband wants more } \\
\text { children }(\text { yes }=1)\end{array}$ & & $\begin{array}{l}.034 \\
(.375)\end{array}$ & & & \\
\hline $\begin{array}{l}\text { Wife wants more children } \\
\quad(\text { yes }=1)\end{array}$ & & $\begin{array}{l}-1.45^{* * * *} \\
(.426)\end{array}$ & & & \\
\hline $\begin{array}{l}\text { Husband's desired } \\
\text { number of children }\end{array}$ & & & & & $\begin{array}{l}.573^{*} \\
(.328)\end{array}$ \\
\hline $\begin{array}{l}\text { Wife's desired } \\
\text { number of children }\end{array}$ & & & & & $\begin{array}{l}1.51^{* * *} \\
(.484)\end{array}$ \\
\hline $\begin{array}{l}\text { Husband's father's age } \\
\text { at husband's birth }\end{array}$ & & & $\begin{array}{l}.037^{* * *} \\
(.015)\end{array}$ & $\begin{array}{l}-.010 \\
(.012)\end{array}$ & \\
\hline $\begin{array}{l}\text { Husband's mother's age } \\
\text { at husband's birth }\end{array}$ & & & $\begin{array}{l}-.027^{*} \\
(.015)\end{array}$ & $\begin{array}{l}.040^{* * *} \\
(.012)\end{array}$ & \\
\hline $\begin{array}{l}\text { Wife's father's age } \\
\text { at wife's birth }\end{array}$ & & & $\begin{array}{l}-.057^{* * *} \\
(.017)\end{array}$ & $\begin{array}{l}.004 \\
(.014)\end{array}$ & \\
\hline $\begin{array}{l}\text { Wife's mother's age } \\
\text { at wife's birth }\end{array}$ & & & $\begin{array}{l}.053 * * \\
(.022)\end{array}$ & $\begin{array}{l}-.007 \\
(.018)\end{array}$ & \\
\hline All baseline controls & Yes & Yes & Yes & Yes & Yes \\
\hline Test ( $p$-value): $\beta_{h}=\beta_{w}$ & .4968 & .7613 & & & .0619 \\
\hline Adjusted $R$-squared & .1677 & .2211 & .1848 & .2402 & - \\
\hline Observations & 177 & 295 & 378 & 378 & 378 \\
\hline
\end{tabular}

Dependent variable is reported in the heading of each column.

Robust standard errors reported in parentheses.

Notes: $* * *$ denotes significance at $1 \%,{ }^{* *}$ at $5 \%$, and $*$ at $10 \%$. Robust standard errors are calculated throughout. The full set of controls as in Tables 5 and 6 is included in all Columns. In Column 1 the sample is restricted to those households in which both spouses reported wanting additional children in MFLS-1. The sample is Column 2 is restricted to those households in which at least one spouse reported wanting additional children in MFLS-1. Columns $3 \mathrm{a}$ and $3 \mathrm{~b}$ report the first stage regressions from the IV regression. The second stage is reported in Column 4 .

average, both spouses want to double their family size from that in MFLS-1. Two further points are of note.

First, there is much less conflict within households over the additional number of children desired than over the total number desired. Second, the additional number of children born after MFLS-1 bears little relation to whether spouses actually wanted more children or not. For example in Malay households, the number of additional children born does not significantly differ between households in which both spouses report wanting more children, only one spouse wants more children, and neither spouse wants more children. This suggests there remains scope for bargaining even if one spouse would prefer not to have any more children.

Table 9 reports estimates of Eq. (18). We first consider those households in which both spouses actually desire additional children. The result in Column 1 suggests that in Malay households, both spouse's fertility preferences have positive, significant, and equal effects on fertility outcomes. The results are qualitatively similar to those in the baseline specification in Table 4. However the estimated effect of husband's preferences on outcomes is now slightly smaller in magnitude than in the baseline specification, and the effect of the wife's preferences is slightly larger. This suggests unobserved household level determinants of fertility, $\varepsilon_{n}$, are positively related to husbands' preferences and negatively related to wives' preferences.

In Column 2 we also use information from households in which at least one spouse wants additional children. ${ }^{40}$ Among these couples, we continue to find the

\footnotetext{
${ }^{40}$ Among couples in which neither spouse wanted more children, there is no variation in the desired number of additional children they are both set to zero. Hence these couples cannot be used to identify $\beta_{h}$ and $\beta_{w}$.
} 
effect of both spouse's preferences on fertility outcomes to be positive, significant, and equal to each other.

The direct effect of the husband wanting more children per se, is not significantly different from zero. In contrast, if the wife wants more children, this leads to significantly fewer additional being born, other things equal. This may capture that in households where the wife wants additional children, her fertility preference is relatively higher than her husbands. As highlighted by theory, if on the margin, by having more children the husband's share of the marital surplus then falls, he will be less willing to contribute to investments into fertility, all else equal. ${ }^{41}$

\subsubsection{Endogenous preferences}

A second concern is that fertility preferences are endogenous to fertility outcomes. Specifically, there may be unobserved individual characteristics that drive both fertility outcomes and fertility preferences. The error term in Eq. (17) then is such that $u_{n d}=\varepsilon_{h n d}+\varepsilon_{w n d}+\varepsilon_{n d}$, where $\varepsilon_{\text {ind }}$ determines the fertility outcome, and the fertility preference of spouse $i, \pi_{\text {ind }}^{*}$. Estimates of $\left(\beta_{h}, \beta_{w}\right)$ in Eq. (17) are then inconsistent.

The endogeneity of preferences could for example arise for example from the private information each spouse has on their health status, knowledge of child rearing practices, fecundity, or use of contraception, that drive fertility outcomes and preferences. These concerns are exacerbated by the fact that at the time preferences are expressed, households are some way into the fertility period. Hence these preferences may also reflect parent's current attitudes towards children based on information revealed over time, such as the true costs and benefits of children. ${ }^{42,43}$

To address this concern we seek instruments for each spouses' fertility preference. These must be correlated with fertility preferences, $\pi_{i n d}^{*}$, and uncorrelated with unobserved individual determinants of fertility outcomes, $\varepsilon_{\text {ind }}$. These are stringent criterion to meet. However, we

\footnotetext{
${ }^{41}$ In line with this interpretation, wives that wanted more children report desiring 5.04 children in total, significantly higher than the 4.3 children desired by women that do not want additional children. Similar results using the same data are also reported in DaVanzo et al. (2003).

${ }^{42}$ For 90 Malay women, information is available on their desired number of additional children in MFLS-2. The majority of women revise their preferences downwards. These revisions are significantly and negatively related to the number of children in the household in MFLS-1, but are unrelated to either spouses' education, age, non-earned income or years married.

${ }^{43}$ In a similar spirit, Rosenzweig and Wolpin (1993) present evidence from the US that mothers use information on their sibling's birth outcomes in evaluating the wantedness of their own children.
}

are able to exploit information on the characteristics of each spouses' parents as potential instruments. The motivation for this instrumentation strategy is that an individual's fertility preference stems partly from their own experiences as a child. In particular, their preference may relate to their own birth order, or number and gender composition of their own siblings. ${ }^{44}$

We do not however directly use the birth order, number or gender composition of each spouse's siblings as instruments. These may be correlated to the support networks available to spouses outside of marriage, and thus may influence behavior within marriage. Rather, we use the age of the husband and wife's own mother and father, at the time when the husband, or wife, were born, as instruments for spouses fertility preferences. The age of spouse $i$ 's parents at the time when he or she was born will be correlated to the birth order of each spouse, and hence may influence their fertility preferences. To be valid, these instruments should have no direct effect on fertility outcomes within the household. ${ }^{45}$

We report the IV estimates in Table 9. Columns 3a and $3 b$ report the relevant coefficients from the first stage. Husbands desire significantly more children if at the time they were born, their father was older or mother was younger. Husbands' preferences are also predicted by the age of the wife's parents, at the time she was born. In particular, husbands desire significantly more children if at the time their wife was born, her father was younger or mother was older. These effects move in the opposite direction to those of the husband's own parents.

The wife's preference is significantly higher, the older was her husband's mother, at the time her husband was born. The fact that each spouses' preference is in part predicted by the age of their partner's parents, makes it less likely that the predicted preferences from the first stage are correlated to spouses' own support networks of family that may drive behavior within marriage.

The second stage is reported in Column $4 .{ }^{46}$ Both spouses' preferences continue to have positive and significant effects on fertility outcomes. Note that the standard errors on both estimates are larger than in the baseline estimates as expected. However, the magnitude

\footnotetext{
${ }^{44}$ This motivation stems from two fields of research. First, demographers have long been interested in whether birth order affects fertility behavior. Johnson and Stokes (1976) present evidence in favor of this. Second, in psychology, some socialization studies have suggested that children brought up in small families, themselves prefer small families. Kahn and Anderson (1992) provide an overview of these studies.

${ }^{45}$ The instruments are not highly correlated with each other. The pairwise correlation coefficients between them are less than .5 .

${ }^{46}$ The instruments pass a Sargan test of overidentification. The $\mathrm{p}$-value on the test is .65
} 
of the effects of each spouse's preferences on fertility outcome are also larger than in the baseline estimates, so that the effect both spouses' fertility preferences on outcomes are underestimated if these preferences are taken to be exogenous to fertility outcomes.

\subsubsection{Measurement Error}

A third concern is that preferences may be reported with error. Suppose that spouse $i$ 's reported preference is equal to $\pi_{\text {ind }}^{*}=\Pi_{\text {ind }}+\omega_{\text {ind }}$ where $\pi_{\text {ind }}$ is their true preference, and $\omega_{\text {ind }}$ is some measurement error. The implications for the estimated coefficients are then similar to when fertility preferences are endogenous. If the measurement error is white noise, the parameters of interest are subject to attenuation bias. This would imply the true effect of each spouse's preference in Malay households is larger than that reported in Table 5. However, the error term $\omega_{\text {ind }}$ may not be white noise for at least four reasons.

First, couples may be unwilling to report true levels of conflict to interviewers, thus biasing their report towards that of their spouse. Second, spouses facing the threat of divorce or a shift in bargaining power may be more likely to agree with their partner. Third, there may be a tendency for individuals to centralize their reports around some acceptable norm. Fourth, errors may arise from misinterpretation of the survey question on fertility preferences, such as if respondents reported their immediate plans rather than their ultimate fertility goals. ${ }^{47}$

This concern is then addressed using the instrumental variables strategy detailed above and reported in Table 9. The evidence suggests the effects of both spouses' fertility preferences on outcomes are underestimated if measurement error in preferences is not accounted for.

\section{Conclusions}

This paper develops and tests a model of household bargaining that sheds light on how fertility outcomes relate to the fertility preferences of spouses. Key to the analysis is whether spouses can commit to their future actions within marriage, such as those relating to investments into child quality. If couples bargain with commitment, fertility outcomes take account of both

\footnotetext{
${ }^{47}$ Around $80 \%$ of spouses were interviewed in the absence of their partner. There are no significant differences in reported fertility preferences, nor in the difference between reports of spouses, depending on the presence of others.
}

spouses' fertility preferences. Hence even if there is conflict, couples behave as if there is a unitary decision making process, and fertility outcomes are efficient. If couples bargain without commitment, the effect of each spouse's preference depends on the threat point in marital bargaining and the distribution of bargaining power. In contrast to standard models of household bargaining, fertility outcomes are inefficient despite couples bargaining efficiently over the distribution of the marital surplus. The Coase theorem breaks down because spouses are unable to commit to ex ante agreements on behavior within marriage.

We test the models using household data from Malaysia. This is an excellent testing ground in which to understand household bargaining, because exogenous differences in threat points in marital bargaining across ethnic groups can be used to help identify the underlying bargaining model. The balance of evidence suggests couples bargain without commitment. The analysis however leaves unresolved the issue of whether couples actually overinvest in fertility relative to the efficient levels that would be achieved if they could bargain with commitment, although the descriptive evidence certainly points in this direction.

Finally, while we have developed and tested a framework for thinking through how non-commitment in marriage determines how conflicts over desired fertility are resolved, these intuitions can be applied to many actions in the household, not just those related to fertility. This offers a broad agenda for future work on the economics of household behavior. ${ }^{48}$

\section{Data sources}

The MFLS comprises a pair of surveys with partially overlapping samples, designed by RAND and administered in Peninsular Malaysia in 1976/7 (MFLS-1) and 1988/9 (MFLS-2). Each survey collected detailed current and retrospective information on family structure, fertility, economic status, and many other topics. Data and documentation for both surveys are available at www.rand.org/labor/FLS. The MFLS-1 sample consists of 1262 households with an ever-married woman, selected to be representative of Peninsular Malaysia in 1976. MFLS-2 reinterviewed 926 of those MFLS-1 households. DaVanzo et al. (2003) report that attrition

\footnotetext{
${ }^{48}$ Pollak (1985) first discussed the role of such transactions costs in marriage. More recently, Lundberg and Pollak (2001) and Aura (2002) have formally considered the implications of such non-commitment for household outcomes.
} 
was not random. Women who had not moved or had not moved far were more likely to be reinterviewed. Compared to those not reinterviewed, reinterviewed women are more likely to be older, from rural areas, and Malay rather than Chinese. However, DaVanzo et al. (2003) provide evidence that attrition was uncorrelated to fertility preferences. We also merged the MFLS data with 1970 and 1980 Malaysia census data, obtained from the South-east Asia Fertility Project Data Archive at the University of Washington. This is accessible via http://csde.washington.edu/research/seafert $/ \mathrm{n} / \mathrm{m} /$ malay_download.html.

\section{Appendix A}

Table A1: Fertility Regressions

Dependent variable $=$ Fertility outcome (number of children ever born, measured in MFLS-2) Robust standard errors reported in parentheses Malay households Chinese households

(1) (2) (3) (4) (6)

All controls No preferences MFLS-2 controls All controls No preferences MFLS-2 controls

\begin{tabular}{|c|c|c|c|c|c|c|}
\hline Husband's desired number of children & $\begin{array}{l}.123 * * \\
(.058)\end{array}$ & & $\begin{array}{l}.138 * * \\
(.061)\end{array}$ & $\begin{array}{l}.000 \\
(.137)\end{array}$ & & $\begin{array}{l}.009 \\
(.150)\end{array}$ \\
\hline Wife's desired number of children & $\begin{array}{l}.155^{* *} \\
(.066)\end{array}$ & $.148 * *$ & $\begin{array}{l}.298 * * \\
(.071)\end{array}$ & $(.123)$ & $.331 * * *$ & $(.127)$ \\
\hline Age & $\begin{array}{l}.071 * * * \\
(.020)\end{array}$ & $\begin{array}{l}.073 * * * \\
(.020)\end{array}$ & $\begin{array}{l}.077 * * * \\
(.023)\end{array}$ & $\begin{array}{l}.131^{* * *} \\
(.021)\end{array}$ & $\begin{array}{l}.141^{* * *} \\
(.021)\end{array}$ & $\begin{array}{l}.135^{* * *} \\
(.022)\end{array}$ \\
\hline Age at marriage & $\begin{array}{l}-.158^{* * *} \\
(.041)\end{array}$ & $\begin{array}{l}-.154^{* * *} \\
(0.43)\end{array}$ & $\begin{array}{l}-.165^{* * *} \\
(.042)\end{array}$ & $\begin{array}{l}-.229 * * * \\
(.036)\end{array}$ & $\begin{array}{l}-.246^{* * *} \\
(.035)\end{array}$ & $\begin{array}{l}-.223 * * * \\
(.038)\end{array}$ \\
\hline Age menstruation started & $\begin{array}{l}.188^{* *} \\
(.086)\end{array}$ & $\begin{array}{l}.192 * * \\
(.087)\end{array}$ & $\begin{array}{l}.217^{* *} \\
(.091)\end{array}$ & $\begin{array}{l}.087 \\
(.074)\end{array}$ & $\begin{array}{l}.092 \\
(.076)\end{array}$ & $\begin{array}{l}.118 \\
(.077)\end{array}$ \\
\hline Wife has some primary education & $\begin{array}{l}-.641^{*} \\
(.362)\end{array}$ & $\begin{array}{l}-.676^{*} \\
(.370)\end{array}$ & $\begin{array}{l}-.466 \\
(.370)\end{array}$ & $\begin{array}{l}-.821^{* *} \\
(.349)\end{array}$ & $\begin{array}{l}-.956^{* * *} \\
(.352)\end{array}$ & $\begin{array}{l}-.723^{* *} \\
(.362)\end{array}$ \\
\hline Wife has completed primary education & $\begin{array}{l}-.109 \\
(.431)\end{array}$ & $\begin{array}{l}-.209 \\
(.445)\end{array}$ & $\begin{array}{l}-.237 \\
(.446)\end{array}$ & $\begin{array}{l}-1.16^{* * *} \\
(.394)\end{array}$ & $\begin{array}{l}-1.30 * * * \\
(.390)\end{array}$ & $\begin{array}{l}-1.04 * * \\
(.430)\end{array}$ \\
\hline Non-earned income $\times 10^{-4}$ & $\begin{array}{l}-.314 \\
(.880)\end{array}$ & $\begin{array}{l}-.955 \\
(.778)\end{array}$ & $\begin{array}{l}-.262 \\
(.865)\end{array}$ & $\begin{array}{l}.387^{*} \\
(.203)\end{array}$ & $\begin{array}{l}.387^{*} \\
(.221)\end{array}$ & $\begin{array}{l}.369^{*} \\
(.198)\end{array}$ \\
\hline Husband has some primary education & $\begin{array}{l}.587 \\
(.389)\end{array}$ & $\begin{array}{l}.569 \\
(.400)\end{array}$ & $\begin{array}{l}.768^{*} \\
(.410)\end{array}$ & $\begin{array}{l}.451 \\
(.510)\end{array}$ & $\begin{array}{l}.439 \\
(.513)\end{array}$ & $\begin{array}{l}.307 \\
(.622)\end{array}$ \\
\hline Husband has completed primary education & $\begin{array}{l}.782^{*} \\
(.460)\end{array}$ & $\begin{array}{l}.767^{*} \\
(.468)\end{array}$ & $\begin{array}{l}.846^{*} \\
(.471)\end{array}$ & $\begin{array}{l}.340 \\
(.533)\end{array}$ & $\begin{array}{l}.215 \\
(.700)\end{array}$ & $\begin{array}{l}.178 \\
(.626)\end{array}$ \\
\hline Husband's non-earned income $\times 10^{-4}$ & $\begin{array}{l}3.73^{* * *} \\
(.964)\end{array}$ & $\begin{array}{l}3.96^{* * *} \\
(.891)\end{array}$ & $\begin{array}{l}3.16^{* * *} \\
(.911)\end{array}$ & $\begin{array}{l}-.336 \\
(1.19)\end{array}$ & $\begin{array}{l}-.182 \\
(1.23)\end{array}$ & $\begin{array}{l}-.646 \\
(1.26)\end{array}$ \\
\hline Husband employed (yes=1) & $\begin{array}{l}2.46^{* * * *} \\
(.751)\end{array}$ & $\begin{array}{l}2.29 * * * \\
(.688)\end{array}$ & $\begin{array}{l}2.51 * * * \\
(.741)\end{array}$ & $\begin{array}{l}1.31 \\
(1.01)\end{array}$ & $\begin{array}{l}1.50 \\
(1.03)\end{array}$ & $\begin{array}{l}1.19 \\
(1.07)\end{array}$ \\
\hline Husband's non-earned income MFLS- $2 \times 10^{-4}$ & & & $\begin{array}{l}-.139 \\
(.608)\end{array}$ & & & $\begin{array}{l}.287 \\
(.624)\end{array}$ \\
\hline Husband employed in MFLS-2 (yes $=1$ ) & & & $\begin{array}{l}.893 * * \\
(.382)\end{array}$ & & & $\begin{array}{l}.200 \\
(.316)\end{array}$ \\
\hline Water supply $($ yes $=1)$ & $\begin{array}{l}-.638 \\
(.440)\end{array}$ & $\begin{array}{l}-.553 \\
(.443)\end{array}$ & $\begin{array}{l}-.360 \\
(.450)\end{array}$ & $\begin{array}{l}-.364 \\
(.343)\end{array}$ & $\begin{array}{l}-.457 \\
(.353)\end{array}$ & $\begin{array}{l}-.247 \\
(.399)\end{array}$ \\
\hline Electric supply (yes=1) & $\begin{array}{l}-.917^{* * *} \\
(.358)\end{array}$ & $\begin{array}{l}-.967^{* * * *} \\
(.358)\end{array}$ & $\begin{array}{l}-.107 \\
(.342)\end{array}$ & $\begin{array}{l}-.391 \\
(.364)\end{array}$ & $\begin{array}{l}-.428 \\
(.372)\end{array}$ & $\begin{array}{l}-.131 \\
(.360)\end{array}$ \\
\hline District fixed effects & Yes & Yes & Yes & Yes & Yes & Yes \\
\hline Test ( $p$-value): $\beta_{h}=\beta_{w}$ & .7584 & - & .9276 & .1558 & - & .1460 \\
\hline Adjusted $R$-squared & .2593 & .2371 & .1925 & .5995 & .5900 & .5877 \\
\hline Observations & 472 & 472 & 453 & 220 & 220 & 209 \\
\hline
\end{tabular}

Notes: ${ }^{* *}$ denotes significance at $1 \%, * *$ at $5 \%$, and $*$ at $10 \%$. Robust standard errors are calculated throughout. Completed primary school corresponds to 6 or more years of schooling. Omitted education category is no schooling. The specifications in Columns 1 and 4 are the same as those reported in Column 4 of Tables 4 and 5 respectively, except now the full set of estimated coefficients is shown. The specifications in Columns 2 and 5 are identical except that both fertility preferences are dropped. The specifications in Columns 3 and 6 additionally control for the husband's employment status and non-earned income in MFLS-2. 


\section{References}

Aura, S. (2002) Uncommitted Couples: Some Efficiency and Policy Implications of Marital Bargaining, mimeo University of Missouri.

Becker, G.S., 1981. A Treatise on the Family. Harvard University Press, Cambridge.

Bergstrom, T.C, Cornes, R.C., 1983. Independence of allocative efficiency from distribution in the theory of public goods. Econometrica 51, 1753-1766.

Bongaarts, J., 2001. Fertility and reproductive preferences in posttransitional societies. Population and Development Review 27, 261-281.

Cameron, A.C, Trivedi, P.K., 1998. Regression Analysis of Count Data. Cambridge University Press, Cambridge.

Chen, Z., Woolley, F., 2001. A Cournot-Nash model of family decision making. Economic Journal 111, 722-748.

Chiappori, P.A, 1988. Rational household labor supply. Econometrica $56,63-90$.

DaVanzo, J., Peterson, C.E., Jones, N.R., 2003. How well do desired fertility measures predict subsequent fertility? Evidence From Malaysia, DRU-3013-NICHD, RAND.

Freedman, R., Freedman, D.S., Thornton, A.D., 1980. Changes in fertility expectations and preferences between 1962 and 1977: their relation to final parity. Demography $17,365-378$.

Grossman, S., Hart, O., 1986. The costs and benefits of ownership: a theory of vertical and lateral integration. Journal of Political Economy 94, 691-719.

Hart, O., Moore, J., 1990. Property rights and the theory of the firm. Journal of Political Economy 98, 1119-1158.

Hirschman, C., Teerawichitchainan, B., 2003. Cultural and socioeconomic influences on divorce during modernization: Southeast Asia, 1940s to 1960s. Population and Development Review 29, 215-253.

Johnson, N.E, Stokes, C.S., 1976. Family size in successive generations: the effects of birth order, intergenerational change in lifestyle, and familial satisfaction. Demography 13, 175-187.

Jones, G.W., 1981. Malay marriage and divorce in peninsular Malaysia: three decades of change. Population and Development Review 7, 255-278.

Jones, G.W., 1994. Marriage and Divorce in Islamic South-East Asia. Oxford University Press, Kuala Lumpur.

Kahn, J.R., Anderson, K.E., 1992. Intergenerational patterns of teenage fertility. Demography 29, 39-57.
Kuchiba, M., Tsubouchi, Y., Maeda, N., 1979. Three Malay Villages: A Sociology of Paddy Growers in West Malaysia. Monograph of the Center for Southeast Asian Studies, Kyoto University.

Leung, S.F (1987). A Theoretical and Empirical Analysis of the Effects of Parental Sex Preferences on Fertility, PhD dissertation, University of Chicago.

Lundberg, S., Pollak, R.A., 1993. Separate spheres bargaining and the marriage market. Journal of Political Economy 101, 988-1010.

Lundberg, S., Pollak, R.A., 2001. Efficiency in marriage. NBER Working Paper, vol. 8642.

Manser, M., Brown, M., 1980. Marriage and household decision theory - a bargaining analysis. International Economic Review $21,21-34$.

Mason, K.O, Taj, A.M., 1987. Differences between women's and men's reproductive goals in developing countries. Population and Development Review 13, 611-638.

McElroy, M., Horney, M., 1981. Nash-bargained decisions: towards a generalization of the theory of demand. International Economic Review 22, 333-349.

Pollak, R.A., 1985. A transaction cost approach to families and households. Journal of Economic Literature 23, 581-608.

Rosenzweig, M.R., Wolpin, K.I., 1993. Maternal expectations and ex post rationalizations: the usefulness of survey information on the wantedness of children. Journal of Human Resources 28, 205-229.

Rudie, I., 1983. Women in Malaysia: economic autonomy, ritual segregation and some future possibilities. In: Utas, B. (Ed.), Women in Islamic Societies: Social Attitudes and Historical Perspectives. Curzon Press.

Swift, M., 1965. Malay Peasant Society in Jelebu. The Athlone Press, London.

Tan, P.C., 1988. The Study of Marriage and Marital Dissolution in Peninsular Malaysia, University of Malaya Faculty of Economics and Administration.

Tan, P.C., Jones, G.W., 1990. Malay divorce in peninsular Malaysia: the near disappearance of an institution. Southeast Asian Journal of Social Science 18, 85-114.

Thomas, D., 1990. Intra-household resource allocation: an inferential approach. Journal of Human Resources 25, 635-664.

Thomson, E., Mcdonald, E., Bumpass, L.L., 1990. Fertility desires and fertility: his, hers, and theirs. Demography $27,579-588$.

Weiss, Y., Willis, R.J., 1985. Children as collective goods and divorce settlements. Journal of Labor Economics 3, 268-292. 